\title{
Dilemma and Factionalism in the Maoist Politics of Nepal
}

\author{
Arjun Bahadur Ayadi
}

\begin{abstract}
The history of the Communist movement of Nepal has passed almost 70 -years since the formation of the Communist Party of Nepal (CPN) in 1949. During this period, the Communist movement of Nepal passes through so many ups and downs, twists and turns, and defeats and victories. It has taken different paths in course of its development. It has experienced series of split and merger, which still continues. The Maoist, a radical faction of the communist movement, led the armed struggle for ten-years between 1996-2006 to seizes political power and establish a "New People's Democracy". However, the deadly armed struggle concluded in negotiation after 10-year and Maoists re-entered in the competitive politics. As it entered in the competitive politics, the CPN (Maoist), revised its ideological goal from "New People's Democracy" to "Democracy in the Twenty First Century". After these ideological change, it has entered in the vicious circle of split and merger. In this context, this paper aims to understand the relations between political dilemma and fraction taken place in the history of Communist movement of Nepal in general and Maoist politics in particular. On the basis of documentary analyses, this paper argues, the whole Communist movement of Nepal including Maoists politics suffered from ideological dilemma (between liberal and radical line) that resulted internal contradiction within the movement leading toward the series of split and generated the serious crisis to radical politics in Nepal.
\end{abstract}

Keywords: CPN (Maoist), Maoism, Marxism, Leninism, ideology

\section{Introduction}

... it will appear that sometimes we are going to the Left and 
sometimes to the Right. In the course of revolution, if one goes Left, then they are Leftists. If they swerve to the Right, then they will be Rightists. We are walking on both legs. Sometimes the left foot leads, sometimes the right foot is forward. It is only by walking on both our feet that we accomplished the ten years of struggle. (Prachanda, 2006, p. 20)

The Maoists were moving to the Right. If there is need, we will once again move to the Left. This is the revolutionary strategy. (Ibid, p. 19)

We are not dogmatic communist and we are prepared to change and debate our belief with anybody. (Washington Post, 22 November 2006)

Karl Marx and Frederick Engels originally propounded the modern concept of the communism in 1840s. However, it failed to pick up any serious resistance in advanced capitalist countries of Europe. Vladimir Ilyich Ulyanov, better known by nom de plume Vladimir Lenin, founder of the Russian Communist Party (RCP) and leader of the Bolshevik Revolution (BR) (1917), gave a new twist on the idea of communism by reinterpreting it in accordance with the realities of pre-capitalist Russia. Over the next few years of the BR, Mao Tse-tung, Chinese Communists leader, architect of Chinese Cultural Revolution (CR), and the Asian interpreter of Marxism, redefined the Marxist-Leninist (ML) doctrine in the context of the Asian agrarian societies with a touch of nationalistic sentiment, anti-colonial, and antiimperialist rhetoric which have still strong appeal in several Asian countries. His idea on Marxism, military strategies, and political policies are collectively known as Maoism.

With the end of World War-II (WW-II), the wave of decolonization or independence movement had taken place all over the world. 
In this context, in the next door of Nepal, the Cultural Revolution under the leadership of Mao in China and decolonization or independence movement under the leadership of Mahatma Gandhi in India got success respectively. Many Nepalese political leaders living in India joined the Indian independence struggle against the British Raj. The reason behind the support of Nepalese political leaders was that it would be helpful to trigger the collapse of authoritarian Rana rule in Nepal if the colonial rule in India ended. Nevertheless, Rana had enjoyed special privileges of British regime. Inspiring from Indian independence movement, the Nepali Congress (NC) party, with principl of liberal democracy, was initially formed in India with the objective of overthrowing the Rana regime in Nepal. Puspa Lal Shrestha, who was affiliated to Nepali Congress in the beginning of his political career, formed the Communist Party of Nepal (CPN) in Calcutta (India) on 22 April 1949'. This establishment of the Communist Party of Nepal had formally introduced the idea of communism or Marxism in the political history of Nepal. Meanwhile, the above cited statements ${ }^{2}$ made by Puspa Kamal Dahal, better known by nom de plume Prachanda, Chairman of the CPN (Maoist), confirmed that the communist movement of Nepal in general and Maoist politics in specific has no consistency and it is being passed through various confusions between Marxist philosophy and liberal democratic framework. Due to the ideological and pragmatic inconsistency,

1 The date of establishment of the CPN has no uniformity, some claimed that CPN was established on 22 April 1949 (when its founder members were agreed to establish CPN) and other argued CPN was established on 15 September 1949 (the date when the CPN made public its first Manifesto). See Bhim Rawal, Nepalma Samyawadi Andolan: Udhbav Ra Bikash (The Communist Movement in Nepal: Origin and Development) (Kathmandu: Saman Prakasan, 1988).

2 Among the three statements, first two statements were made immediately after the 12-Point Understanding agreed between the then CPN (Maoist) and the Seven Party Alliance (SAP) in 2005 and third one was made after signing the Comprehensive Peace Agreement (CPA) 2006. 
the communist movement of Nepal has not only become fragile but also supposed to reach the point of liquidation.

In this context, this paper has attempted to explain how the communist movement of Nepal in general and Maoist politics in particular suffered from the political dilemma and fraction. For the purpose, the paper is divided into three sections. First, it briefly draws a picture of how the political dilemma and fractions in the communist movement of Nepal led to the origin of the CPN (Maoist). The second section examines the ups and downs of a decade long Maoist armed struggle that caused political dilemma and fractions within the Maoists themselves. Finally, the paper tries to narrate the political dilemma and fraction in the Maoist after its entry into the competitive electoral politics.

\section{Methodological Aspects}

This article is the outcome of five years' long rigorous study of the communist movement of Nepal in general and Maoist politics in specific in between 2013-2018. To fulfill the objectives of the study various sources of information have been collected and consulted during the study period. Primary information has been collected from the documentary sources, such as party documents. The formal and informal talk with different people involved in communist movement of Nepal, either as a leader, cadre, or analyst also become helpful. Along with the primary sources of information, to address the theoretical aspects and historical information about the subject matter, different books, journals, newspapers, and other secondary sources of information are also used in this peace of writing. Although the piece of writing is the combination of documentary and empirical information, it has primarily relied on the method of documentary analyses. 


\section{Maoist Movement as an Outcome of Dilemma within Communist Movement of Nepal}

The communist movement of Nepal is the outcome of inspiration of the Indian communist rooted in the independence movement of India. Political activists who were disappointed with NC leadership led the formation of communist party of Nepal. During the inaugural session of the party, CPN stated that, "Nepal should establish a 'new democracy' as in China, if necessary through armed struggle so as to create a People's Republic" (CPN, 1949). CPN initially declared itself as the true representative of the proletariat class of Nepal and it expanded the support base throughout the country within a short period of time. Because of the wider support base, immediately after the end of Rana regime in Nepal peasant movement spread against proprietor in rural parts of Nepal. But, because of the ideological confusion and dilemma of leadership, the CPN was unable to lead the movement.

Differences within the leadership of CPN regarding the future strategy of the party came into the surface during the second congress of CPN held in 1957. Disagreements aroused over the issues of Constituent Assembly (CA) and parliamentary democracy proposed by Puspa Lal Shrestha, republican system by Sambhu Nath Shrestha, and constitutional monarchical system by Keshar Jung Rajamajhi (Rawal, 1991, p. 51). These differences and disagreements had affected all the structures and units of the party. The units and structures were divided according to the loyalty towards the particular leaders and began to act independently. This phenomenon led to a further crisis in the communist movement of Nepal.

The CPN criticized the 1950's political change as having no political significance since it was not a total revolution 
(Adhikari, 1951). But it decided to join the democratic process and participated in the election for parliament in 1959. The CPN won four constituencies out of 109 in the parliamentary election. In 1960, King Mahendra seized the power and directly ruled the country introducing party-less Panchyat system. During the Darbhanga Plenum of CPN, the clear division of leadership was seen. Leaders were divided in for and against the King's political takeover. The faction led by Keshar Jung Rayamajhi had supported the king's move by advocating the idea of constitutional monarchy. Whilst, Pushpa Lal Shrestha led faction had opposed the royal coup and favored the mass movement as proposed by NC. This division led to the split of the CPN into the CPN Pushpa Lal Shrestha group and the CPN Rayamajhi group. Later, CPN Rajamajhi group joined the government led by the King under party less Panchayat system. With this incident, the series of split and merger began in the communist parties of Nepal. Nirmal Lama and Mohan Bikram Singh formed a CPN 'Central Nucleus' in 1971 and agreed to continue the "protracted People's War" (PW) as the party's strategy departing significantly from the line that the establishment was practicing. However, Pushpa Lal Shrestha was against the PW but advocated the need of "United Movement", jointly with the $\mathrm{NC}$, against the absolute monarchy.

Inspired from Chinese Cultural Revolution and Naxalite movement of India, a group of young leaders of CPN launched the armed uprising with the aim of eliminating class enemies in Jhapa district in April 1962. The revolt is popularly known as Jhapa Bidroha in the communist history of Nepal. The Panchayat regime has easily crushed the rebellion and taken the situation under control. Although the revolt could not be successful, the Jhapa incident had significant implication in the future course of the communist movement of Nepal. Nonetheless,

Dilemma and... Arjun Bahadur Ayadi - 6 - 
Koshi Regional Committee of the CPN, which led to the Jhapa Bidroh, was developed as the All Nepal Revolutionary Coordination Committee (ANRCC) in 1975 and later it emerged as the CPN (Marxist-Leninist), CPN (ML), under the leadership of Manmohan Adhikari in 1978. The CPN (ML) gave up the line of PW in 1979 and emphasized to "Nepali Road to Socialism" based on an understanding of economic and social conditions in Nepal (Rawal, 1991, pp. 80-87). Due to the severe state repression, CPN (ML) popularly known with Nepali acronym "Ma-Le" abandoned the path of armed struggle for mass based movement as a road to socialism (Mikesell, 2004, p. 8).

On the other hand, the extreme communist group organized the Chautho Mahadhibeshan (Fourth Convention was) ${ }^{3}$ in the initiation of Mohan Bikram Singh and Nirmal Lama in 1974. The Fourth Convention continued the decision of 'Central Nucleus' and re-endorsed the PW as a future strategy of the party. Meanwhile, the King Birendra declared Janmat Sangrah (Referendum) on 24 May 1979 responding towards a month long nationwide student movement. The CPN (Fourth Convention) initially announced an active boycott but it changed its stand to participate in the referendum without any pre-condition at the last moment (Rawal, 1991, p. 148).

The Fourth Convention also divided in 1983. CPN (Masal) was formed out of the Fourth Convention. The CPN (Masal) further split into the CPN (Mashal) in 1984. Mohan Baidya became the General Secretary (GS) of the CPN (Mashal) and continued PW based on guerrilla warfare as its course. When the radical line of the communist movement gradually losing its public support due to the regular split, the CPN (Mashal) launched

3 The top Nepali Maoist leaders- Mohan Baidhya, alias "Kiran"; Puspa Kamal Dahal, alias Prachanda; Chandra Prakash Gajurel, alias "Gaurav" and Ram Bahadur Thapa, alias "Badal" are all belonged to this communist faction.

- 7 - Journal of Political Science, Volume XVIII, 2018 
an urban insurrection (popularly known as Sector Kanda) in 1989 attacking the local police posts at Kathmandu, capital city of Nepal. However, this insurrection was not successful and ended with the arrests of many party cadres. The Central Committee (CC) of the party deemed it as a mistake and forced Mohan Baidhya to resign from the post of GS. Mohan Baidhya's resignation led to the promotion of Prachanda as new GS of the CPN (Mashal) (see K.C., 2006 for more details).

On February 1990, Jana Andolan-I (People's Movement-I) under the leadership of NC began in order to end autocratic Panchayat regime and restore multiparty democracy in the country. At that time, the communist parties formed two alliances: the United Left Front (ULF) ${ }^{4}$ and United National People's Movement $(\mathrm{UNPM})^{5}$. The ULF joined the People's Movement-I from the beginning. With the initial reluctance, the UNPM, particularly CPN (Mashal), participated the people movement when the street protest had gained the momentum. Royal proclamation reinstated the multiparty democracy and ended the People Movement-I on 8 April 1990. Two alliances of the communist parties reacted differently towards the royal proclamation. The ULF welcomed the proclamation and announced that the People Movement-I was successful. However, the UNPM rejected the royal proclamation and continue the movement demanding the election for Constituent Assembly (CA) and the abolition of the monarchy. UNPM halted the mass protest because of few people shown up in the street. On November 1990, new constituion was promuglated having the main essence of multiparty parlimentary democracy and constitutional monarchy.

4 ULF includes a group of moderate left parties- 1) CPN (Marxist-Leninist), 2) Nepal Workers and Peasants Party (NWPP), 3) CPN (Fourth Convention), 4) CPN (Marxist), 5) CPN (Burma), 6) CPN (Manandhar), and 7) CPN (Amatya).

5 UNPM includes a group of extremist communist parties- 1) CPN (Mashal), 2) CPN (Masal), 3) Nepal Marxist-Leninist Party, 4) Nepal Communist League, 5) CPN (Nanda Kumar Faction), and 6) Proletariat Labour Organization).

Dilemma and... Arjun Bahadur Ayadi - 8 - 
The merger of radical communist parties of Nepal happened immediately after the promuglation of new constitution. The CPN (Unity Centre) was formed on November 1990 through the merger of four splinter group of communist parties ${ }^{6}$ and Prachanda became the GS of the newly formed party. The Unity Centre rejected the new constitution declaring it as inadequate for a genuine democracy and did not show its interest to take part in the election scheduled for May 1991 (Karki and Seddon, 2003, p. 15). However, the Unity Centre had changed its previous position and took part in the parliamentary election under the banner of Samyukta Janamorcha Nepal (United People's Front of Nepal- UPFN). In this election, the UPFN won Nine constituencies out of 205 constituencies in the parliament.

In December 1991, the CPN (Unity Centre) organized its first unity congress and adopted the "Marxism-Leninism-Maoism" as its ideological base. Furthermore, the congress denounced the recently established parliamentary system as incapable for progressive change and approved PW along with Chinese model as its path (Prachanda, 1991) opposing the proposal of "mass uprising" presented by Nirmala Lama. During the mid-term election 1994, the Unity Centre split into two factions one led by Prachanda and another by Nirmal Lama advocating armed struggle and people uprising respectively. During the party registration process of mid-term election 1994, the Election Commission (EC) recognized the UPFN belonged to Nirmal Lama camp as official. After being rejected from the official registration, UPFN led by Baburam Bhattarai and belonged to Prachanda camp had boycotted the mid-term election. It is said that the decision of EC was one of the reasons behind

6 CPN (Unity Centre) includes- CPN (Mashal) led by Prachanda, The Fourth Convention led by Nirmal Lama, The CPN (Janamukti), and Proletarian Workers Organization led by Ruplal Bishwakarma. Similarly, a splinter group of the CPN (Masal) led by Baburam Bhattarai and Shital Kumar joined the Unity Centre.

- 9 - Journal of Political Science, Volume XVIII, 2018 
the emergence of the CPN (Maoist) and one of the triggering points to endorse armed rebellion as the course of the CPN (Unity Center) led by Prachanda. Dalit Liberation Front, sister organization of CPN (Unity Center) led by Prachanda, carried out the anti-untouchability movement in october 1994 in the name of SiJa campaigning in Rolpa district ${ }^{7}$ in the line of the preparation of armed struggle. This SiJa campaign included Miteri Abhiyan (friendship campaign) and Jansewa Abhiyan (serving the people campaign).

On March 1995, CPN (Unity Center) led by Prachanda organized its third expanded meeting of the Central Committee (Plenum). The meeting decided to change the name of the CPN (Unity Centre) into the CPN (Maoist). In addition, it took a decision to quit parliamentary politics and declared the inefficiency of parliamentary democracy for progressive change in the country. It also took a decision to prepare ground for armed struggle in the country. Further, the CC meeting of CPN (Maoist) held in September 1995 adopted the Plan for Historical Initiation of People's War as its policy paper for armed struggle.

\section{Maoist Dilemma during Armed Struggle}

The UPFN led by Baburam Bhattarai and affiliated to CPN (Maoist) presented the 40-point demand ${ }^{8}$ to the government on 2 February 1996. The 40-point demand was not more than a list

7 The UPFN's underground party committee had organized this campaign to provide the political education for their party cadres of the two districts: Rukum and Ropla. The SiJa campaign was named after two mountains peaks and villages: Sisne and Jaljala located respectively in Rukum and Rolpa district and familiar symbols of the Kham Magar ethnic group of people living in the area. A senior Maoist leaders Badal led the SiJa campaign. The meaning of the SiJa campaign was also derived from English word "siege" means to capture state power from the feudal landlord, usurers, and comprador bourgeoisie.

8 List of 40-point demands was related to nationalism, democracy, and livelihood not much different from the points outlined in the 1991 election manifesto. For more detail see, UPFN election manifesto 1991 and 40-point demands presented by UPFN chairman Baburam Bhattarai to the government on 2 February 1996.

Dilemma and... Arjun Bahadur Ayadi - 10 - 
of social grievances under the liberal democratic framework contrary to the previous claim of September CC meeting9. However, the government did not respond to the demand and this was considered one of the immediate factors behind the start of Maoist armed struggle throughout the country on 13 February 1996. Meanwhile, the Maoist armed struggle did not match the essence of PW as they claimed. Instead of strengthening the public support and broadening the base area as per the basic principle of PW, the Maoists adopted terror as their basic weapon from the very beginning of the armed rebellion. The Maoists applied hit-and-run strategy and carried out thousands of assaults in the name of "people's actions" including propaganda, sabotage, and guerrilla actions. During the Fourth Plenum held in August 1998 at Faridabad, India, the CPN (Maoist) took a decision about the development of base area and guerrilla zone. For the purpose, Maoists adopted the slogan "march forward to the direction of building base area" (People's March, 2001) and began to declare the base area (mostly of rural parts) without the effective control in the areas.

In February 2001, the CPN (Maoist) introduced Prachandapath as the guiding principle of Nepali Maoist during its second national convention held at Punjab, India (Prachanda, 2001). This introduction of Prachandapath had increased contradiction and dilemma within the Maoists as well as it divided the Maoists into two lines: radical and moderate. The radical line led by Mohan Baidhya emphasized on military strategy and violent measures to achieve "New People's Democracy" whereas moderate line led by Bhattarai did not denounce violent measures but ready to consider taking a cooperative path. Whilst, Prachanda had no

9 In a document "Plan for Historical Initiation of People's War" adopted by the CPN (Maoist) CC meeting held in September proclaimed that, their first and immediate concern was to complete the "New Democratic Revolution" through PW based on Marxism-Leninism-Maoism (MLM).

- 11 - Journal of Political Science, Volume XVIII, 2018 
clear stand and played cleverly in between two lines according to the situation. In the changing context and with the elapse of time, the radical line became weak and a moderate vision gained ground. ${ }^{10}$

The ideological dilemma among the Maoists further came into the surface after the palace massacre on June 2001. In one hand, Maoists presented their demand of republic to government during the negotiation (first round in July 2001) and on the other hand, they claimed that they had Aghoshit Karyagat Ekata (hidden working alliance) with the assassinated King Birendra (Tarun Weekly, 2001) and decided to join the government under the leadership of new King Gyanendra (Bastola, 2008, p. 5). However, neither the negotiation became success, nor the Maoist plan to join king's government converted into reality. In the second round of negotiation from January to August 2003, the CPN (Maoist) withdrew its previous demand for republic and forwarded the demands including a round-table conference; an interim constitution and interim government; and elections to an inclusive CA to draft a new constitution (Pathak, 2005, pp. 354-56). In between, the CPN (Maoist) organized its CC meeting in May/June 2003 at Rolpa and adopted a document named the Development of Democracy in the Twenty-first Century (DDTC). This document was the further explanation of Prachandapath that advanced the working idea in a multiparty competitive democratic system within the stipulated constitutional framework. ${ }^{11}$ With the introduction of DDTC, the

10 On 14 December 2002, in an interview Baburam Bhattarai explained that his party was "not pressing for a 'communist republic' but a bourgeois democratic republic." In addition, he repeated the Maoists' "commitment to a multiparty system" and he mentioned that "diplomatic and friendly relations with all the countries of the world", Washington Time, 14 December 2002, retrieved from http://www.washingtontimes.com/news/2002/dec/14/20021214-105150-2928r/ on 21 August 2017.

11 Santanu Dey, “Advance of the Maoists in Nepal: From Armed People's War to the Long March towards People's Democracy”, Retrieved from http://www.pragoti.

Dilemma and... Arjun Bahadur Ayadi - 12 - 
radical line within the party lost the ground. The CPN (Maoist) discarded its previous line of one party system and endorsed the pluralist political system.

During the CC meeting of the Maoist held in Funtiwang (Rolpa) in August 2004, the heated debate took place between two groups regarding the primary enemy of the armed struggle. The radical group identified India as the primary enemy since India supported the King and was pressing for the preparation of strategic offensive action. The moderate faction headed by Baburam Bhattarai argued monarchy as the main enemy of the Maoists and other option should remain open not only strategic offensive action. The rift between two lines was so intense that the party almost reached on the verge of split; Prachanda was alleged of being "agent of Palace" and Baburam Bhattarai alleged of being "agent of India". The politburo meeting of the party decided to take punitive action against the leaders of moderate line and three leaders Baburam Bhattarai, Dina Nath Sharma and Hisila Yami suspended from all the portfolios of the party (Ogura, 2008, p. 21). The Maoist adopted strategic offensive action as its official line.

In the political twist, the King Gyanendra dismissed the elected government and began his direct rule on 1 February 2005. The CC meeting of the Maoist in October 2005 held in Rukum district, famously known as Chungwang meeting, reached a conclusion that they could not capture state power by force. The meeting withdrew the disciplinary action taken against the leaders; reviewed the official line of the party; decided to go with the multi-party democratic republic as the immediate tactics; and set out the terms of agreement with parliamentary political parties (Prachanda, 2005). Mohan Baidhya, the main leader of the radical line, could not attend the Chungwang meeting because 
he was arrested in India in March 2004. After the meeting, 12-points understanding between CPN (Maoist) and Seven Party Alliance (SPA) concluded in 22 November 2005 that became basis of Jana Andolan-II (People's Movement -II) 2006. With the success of People's Movement-II, the Comprehensive Peace Agreement (CPA) between the government and the Maoist concluded in November 2006 and the Maoist formally entered into the electoral politics in Nepal.

\section{Re-entry into Electoral Politics and Maoist Dilemma}

On the basis of 12 point understanding, Jana Andolan -II (People's Movement-II) started and got success in reinstating the dissolved parliament and restoring the multi-party democracy on 24 April 2006. The CPN (Maoist) accepted the outcome of the movement with reservation. After the success of Jana Andolan$I I$, interim government was formed under the leadership of Girija Prasad Koirala. Comprehensive Peace Agreement (CPA) was signed between government and Maoists on 21 November 2006. The interim constitution was promulgated in 15 January 2007. As per the agreement, the Maoists got 83 MPs in the interim parliament. Finally, Maoists entered into the interim government led by Girija Prasad Koirala on 1 April 2007 and Maoist armed struggle came to a formal end. However, the Maoists still presented themselves as a vanguard revolutionary that shows the difference between the policies taken by the party and actions taken by the Maoist leadership. The Maoist leadership warned publicly to the other party's leaders, cadres and ordinary people by saying if the "reactionary forces" derail the peace process of a "democratic republic" they would not hesitate to use more traditional revolutionary tactics and initiate mass insurrection (as October Revolution) (Gobyn, 2009, p. 433). The Maoist reorganized their militant youth wing, the Young Communist 
League (YCL) ${ }^{12}$, into a nationwide organization under the leadership of former PLA commanders. The CPN (Maoist) had openly carried out extra legal or wartime activities e.g. force, seized public property (Outlook India, 2007); and attack against security force (Refugee Review Tribunal, n.a.).

In the extended CC meeting (Plenum) at Balaju, Kathmandu in August 2007, the radical line of the party became dominant over the moderate. The hardliner leaders- Mohan Baidhya and Netra Bikram Chand emphasized the necessity of urban insurrection, the immediate declaration of republic by the interim legislative parliament and the full proportional representation (PR) system in every organs of the state. This meeting also took a decision to launch the peaceful protest in order to declare the republic before the CA election at all levels-the government, the parliament, and the street. As a result, the Maoist submitted 22-points demand to the coalition government in which Maoist itself a coalition partner. Likewise, the ministers of Maoist resigned from the government on 18 September 2007 but resumed the post after an agreement on the end of December.

The CPN (Maoist) emerged as the largest party in the CA election held on 10 April 2008 winning 229 seats out of 601seats. Immediately, after the numerical change in the CA cum parliament, the CPN (Maoist) had emphasized on the constitutional amendment towards the presidential government with full executive authority but other political parties rejected that. The issue of constitution amendment created the political stagnation for more than three months. Only after three months of CA election, Prachanda became Prime Minister of Nepal by

12 According to a database, since the CPA came into effect in November 2006, 22 persons were killed and 772 people were abducted by the Young Communist League (YCL), the Maoist youth wing, over a period of one year (November 2006-December 2007) South Asia Terrorism Portal, retrieved from http://www. satp.org/satporgtp/sair/Archives/6_23.htm on 25 August 2017.

- 15 - Journal of Political Science, Volume XVIII, 2018 
the overwhelming support of 464 MPs $^{13}$ on15 August 2008. Increasing conformation and dilemma within the Maoists and between the Maoists and other parties had pushed the Nepali state towards political instability and uncertainty. Meanwhile, the prominent leader of radical faction of Maoist, Mohan Baidhya, resigned from the membership of constituent assembly on 20 October 2008 advocating for the single party Communist dictatorship in Nepal contrary to the party official line after Chungwang meeting.

During the national conclave of the Maoist held on 1726 November 2008 at Kharipati, Bhaktpur, the key leaders representing two lines produced two separate political documents. Prachanda in his document emphasized on gradual move towards the people's democracy creating a favourable environment with the support of people (Prachanda, 2008). Baidhya in his political document claimed that a suitable time had come for an urban insurrection and setting up a "People's Democracy". Baidhya also blamed Prachanda group that they became too much flexible in negotiations with other political parties diverting the spirit of the ten-year long armed struggle and leading to a luxurious path after holding power (Baidhya, 2008). After several level of discussion, the conclave ended with a consensus to incorporate both the document and produce a new one and altered the party's goal from "federal democratic republic" to "People's federal democratic republic" reasserting the party's radical leftist aspirations (Sigdel, 2008). The result of this conclave was that the leaders and cadres fragmented into two groups. On 13 January 2009, the unification of CPN (Maoist) and CPN (Unity Centre- Masal) had happened and renamed the

13 The 21 political parties elected to the CA announced their support to the CPN (M), while the People's Front of Nepal and the Nepal Workers and Peasants Party boycotted the PM election. The CPN-UML and the Madhesi Janadhikar Forum joined the cabinet. The NC decided to remain in the opposition.

Dilemma and... Arjun Bahadur Ayadi - 16 - 
party as Unified Communist Party of Nepal (Maoist), UCPN (Maoist). Dissatisfied with the unification, Matrika Yadav, Madheshi leader, broke away from UCPN (Maoist) and formed the CPN (Maoist) in February 2009. He blamed the UCPN (Maoist) leadership as corrupt, opportunist, and deviated from the aspiration of Madhesi people. This had begun the vertical split in Maoist party after getting re-entry into electoral politics.

The contradiction that was taking place within the Maoists also reflected in the Prachanda led government activities and Maoists' behavior in the parliament and outside. During his premiership, Prachanda accused the state institutions like: judiciary, bureaucracy, security forces, and media house for not cooperating to his action. His government attempted to sack the Army Chief of Staff (COAS) and removed the Indian priest from Pashupatinath temple, the most sacred Hindu temple in Nepal. In row over the sacking COAS, Prachanda resigned from the post of Prime Minister on 04 May 2009. In order to uphold the civilian control over the military in the country, Maoist launched regular protests and obstructions in the parliament. Such protests and obstructions were also meant to end American imperialism and Indian expansionism in the country.

The line struggle within the UCPN (Maoist) had become more vivid in Palungtar plenum organized on 21-28 November 2010. Three separate political documents were presented by Prachanda, Mohan Baidhya and Baburam Bhattarai. The political document of Prachanda, Chairman of the party, includes the peace and constitution making as the top priority for the future course of the party whilst armed revolt as second option. Furthermore, Prachanda emphasized that the party would have to revolt if the traditional forces within the country and imperialist and expansionist forces were to sabotage the process of peace and 
constitution. Prachanda also stated that domestic feudalism and Indian expansionism as the party's principal enemy (Prachanda, 2010). Ideologically, the political documents of both Prachanda and Baburam had similar line and view. However, Baburam Bhattarai, vice-chairman and leader of moderate line of the party, presented different view regarding the identification of the principal enemy of the party. According to him, domestic feudalism is the principal enemy and the party should first defeat domestic feudalism; the intermingling of feudalism and Indian expansionism as a principal enemy only encourages the counterrevolution (Bhattarai, 2010). Mohan Baidhya, vice-chairman and radical line of the party argued that the peace process had already reached the point of saturation and emphasized the capture of state power through people's insurrection in order to establish people's democratic republic. His view was that it is impossible to achieve socialism and communism without military means in Nepal. However, Baidhya agreed with Prachanda regarding the identification of the principal enemy (Baidhya, 2010). Both the vice-chairmen accused Prachanda for the misuse of power and authority and financial irregularities. The plenum ended without approving the common political document because of the wider differences within the party. But the plenum concluded that the decision regarding the correct ideological line to be taken by the party would be made from the national conclave or general convention.

From this plenum, the dilemma of the Maoist had come into surface clearly and the line struggle was not limited to theoretical level. The desire for more power among the top leaders of the party and organizational disputes relating to the allocation of organizational seats in the party to the members of different factions had also grown up to organizational and personal level, too. After Palungtar Plenum, the UCPN 
(Maoist) hold its first CC meeting on 18 December 2010. The CC meeting had adopted the people's revolt as the immediate programme to capture power (Republica, 2010) overturning the political line adopted in Chungwang meeting five-year before. Similarly, India was identified as the principal enemy of the party in Palungtar plenum. In Chungwang meeting, the political line adopted was the capture of state power through peaceful means. Similarly, India was considered to be a friend. However, Baburam Bhattarai registered his dissent in the party, arguing that institutionalization of the achievement should be the first priority of the party against the $\mathrm{CC}$ decision in Palungtar plenum (Republica, 2010).

The political line that had taken during the Palungtar plenum could not remain for a time. Prachanda, who keeps on vacillating between hardliners and moderate workers within the party, presented a brief political document that included the moderate line of peace and constitution in the Politburo meeting in 20 April 2011. Furthermore, he argued that there was a real risk of counter-revolution in the country and chances to lose the political achievement made so far, if the party would not put its best effort for peace and constitution. He also put forward three reasons, massive changes in the objective reality for revolution; chances of counter-revolution had been raised during the period; and needed more homework for revolt, that compelled his ideological shift (Prachanda, 2011). Criticizing the new political document presented by Chairman, Mohan Baidhya argued that it is against the fundamental spirit of official political line that adopted by the Palungtar Plenum. Furthermore, Baidhya claimed that it was a serious ideological deviation towards rightist and against the proletariat dream of revolution (Baidhya, 2011). This confrontation between the two lines was settled in the CC meeting started from 27 December 2011 and ended on 17 
January 2012 by taking the middle path. This meeting adopted "People's democratic republic" as its immediate policy until the completion of constitution drafting process keeping the option open for "People's Revolt" (Kathmandu Post, 2012).

The continuous intra-party rifts in the UCPN (Maoist) reached to the point of split when the Prachanda, Chairman of the party, agreed the regrouping of the Maoist Army Combatants (MACs). The situation is further complicated after the special committee for the reintegration of MACs gave an order to Nepal Army (NA) and Armed Police Force (APF) to take control of the cantonments of MACs on 10 April 2012. The hardliner fraction of the party harshly reacted to the situation and formed People's Revolutionary Bureau (PRB) comprising 17-members under the leadership of Netra Bikram Chand, member of the Standing Committee (SC). Parallel to the PRB, Prachanda and Baburam Bhattarai's fraction formed the Ex-People's Liberation Army (PLA) association under the leadership of former PLA chief, Nanda Kishor Pun, on 27 April 2012. Finally, hardliner faction held a national gathering on 16 to 18 June 2012. As per the decision of the national gathering, Communist Party of Nepal-Maoist (CPN-Maoist) was formed under the leadership of Mohan Baidhya on June 2012.

The Seventh General Convention of UCPN (Maoist) held on 2-7 February 2013 at Hetauda has changed the political course of the party. The UCPN (Maoist) will follow the liberal competitive politics as its future political line; emphasizes the economic revolution through capitalism in order to reach socialism; and declares that political revolution has been over (Prachanda, 2013). After the split, the UCPN (Maoist) had been somehow free from internal friction and political dilemma but the road ahead to broaden the popular support is the hardest to chew. 
On the other hand, the CPN-Maoist remained undecided regarding its future political line. The leaders of the party firmly iterated that it will not follow the parliamentary democracy and will not take part in the elections. CPN-Maoist set the people's revolt instead of people's war as its future political line during the general convention held on 9-13 January 2013. But the party was not able to restore the armed revolt immediately. Such prolonged situation of indecisiveness resulted into the emergence of faction within the party. Netra Bikram Chand, General Secretary of the party, led the group of hardliner and pushed for immediate restoration of the armed struggle as per its political line of the party. But Mohan Badhiya, Chairman of the party, was reluctant to initiate the armed struggle. This contradiction led the party towards the split. The dissent faction led by Netra Bikram Chand organized a four-day long meeting on 20-23 November 2014 and concluded to form a new party called the CPN (Maoist). As per the decision of the meeting, Netra Bikram Chand "Biplab" declared the dissociation from the party by submitting a divorce-letter to the party headquarters on November 24, 2014. The breakaway faction led by Biplab has chosen the radical political line and most of the leaders have remained semi-underground in order to establish "People's New Democracy" through PW. The CPN-Maoist led by Mohan Baidhya is still wandering with political dilemma ${ }^{14}$ even after its relegation in terms of size and credibility.

\section{Conclusion}

After the brief overview of communist movement of Nepal in general and Maoist politics in particular, the inference could be made that the rightist political line openly dominated the

14 The First National Assembly meeting of the CPN (Maoist-Revolutionary) that has recently concluded (held at Pokhara during 9-11 October 2017) took the decision to participate in provincial and federal parliamentary election scheduled for 26 November and 7 December 2017 against its previous stand not to participate in parliamentary democratic election. 
Nepalese communist movement since its inception. Because of rightist line, the communist parties are not guided by true essence of communist ideology in the country. Utmost desire for power among the top leaders of the party has created personality clash, ambiguity of idea and dilemma of struggle strategy that led the Communist movement of Nepal supposed to collapse through a series of split and merger. The histroy of the communist movement of Nepal also revealed that every splinter group of the communist movement projected themselves as more radical than old group however it becomes futile immediately.The Maoist politics of Nepal has also suffered from this general trend. Ideological dilemma and internal contradiction within Maoists has made the party to revise its political line and ideological goal since 2001. These revisions allowed the party to join parliamentary politics under multiparty democracy. However, the idological dilemma and increasing internal rifts within the Maoists generated the serious crisis to Maoist politics in particular and the radical politics of Nepal in general.

\section{Reference}

Adhikari, M. M. (1951). Text of Political Document. Endorsed by the First Convention of the CPN held in 1951.

Baidhya, M. (2008). Text of the Political Document. Presented in Kharipati National Convention of the CPN (Maoist) on 17-26 November 2008.

(2010). Text of the Political Document. Presented at Palungtar Plenum on 21-28 November in Gorkha.

-----(2011). "Present Revolutionary Crisis and Our Task". A Political document presented in the party's CC Meeting held in April 2011. The Red Star, 19 June 2011, retrieved from https://southasiarev.wordpress.com/2011/07/19/ nepal-kiran-on-the-present-revolutionary-crisis/ on 26 August 2017.

Bastola, D. (2008). "Historic CC Meeting and Its Historic Task", The Red Star, 1:3, 1-15 June 2008, p. 5, retrieved from http://bannedthought.net/Nepal/RedStar/ TheRedStar-vol1-09.pdf on 02 September 2017.

Bhattarai, B.(2010). Text of the Political Document presented at Palungtar Plenum on 21-28 November 2010 in Gorkha District.

CPN (1949). Leaflets distributed by the CPN to the people in 1949.

Daily Telegraph (31 Oct 2006). Retrieved from http:/www.telegraph.co.uk/news/ worldnews/1532891/Nepals-fierce-one-spurns-Chairman-Mao-and-claimscentre-ground-in-peace-talks.html on 20 August 2017

Dey, S. (n. a.). Advance of the Maoists in Nepal: From Armed People's War to the 
Long March towards People's Democracy. Retrieved from http://www. pragoti.in/bn/node/1236on 13 July 2016.

Gobyn, W. (2009). "From War to Peace: The Nepalese Maoists' Strategic and Ideological Thinking”. Studies in Conflict \& Terrorism, 32:5, (2009), p. 420438.

K. C., S. (2006). Nepalma Communist Andolanko Itihas- Dosro Bhag (History of Communist Movement in Nepal- Vol. 2). Kathmandu: Bidyarthi Pustak Bhandar.

Karki, A. and Seddon, D. (2003). "The People's War in Historical Context”. In Arjun Karki and David Seddon (eds.), The Peoples; War in Nepal: Left Perspective. Delhi: Adroit Publishers.

Kathmandu Post, 18 January 2012.

Lawoti, M. (2010). "Evolution and Growth of the Maoist Insurgency in Nepal". In Mahendra Lawoti and Anup Kumar Pahari (eds.) Maoist Insurgency in Nepal: Revolution in the 21st Century. London: Routledge.

Mikesell, S. (2004). "Prajatantra" (Democracy). In Mary Des Chene and Pratush Onta, (eds.), Nepalko Sandarbhma Samajsastriya Chintan (Sociological Perspective on the Context of Nepal). Kathmandu: Social Science Baha, pp. 6-9.

Nickson, R. A. (1992). "Democratisation and the Growth of Communism in Nepal: a Peruvian Scenario in the Making?" Journal of Commonwealth and Comparative Politics, 30: 3 (Nov. 1992), pp. 358-86.

Ogura, K. (2008). Seeking State Power-The Communist Party of Nepal (Maoist). Berlin: Berghof Research Center for Constructive Conflict Management.

Outlook India (22 April 2007). "Nepal Maoists Seized King's Property". Retrieved fromhttps://www.outlookindia.com/newswire/story/nepal-maoists-seizekings-property/467336 on 25 August 2017.

Pathak, B. (2005). Politics of People's War and Human Rights in Nepal. Kathmandu: BIMIPA Publications.

People's March, 2: 1 (2001), retrieved from http://www.bannedthought.net/India/ PeoplesMarch/PM1999-2006/archives/2001/jan2k1/nepal.htm on 22 July 2016.

Prachanda (1991). Text of Political Line of CPN (Unity Center). A Political document adopted by the Unity Congress of the then CPN (Unity Centre) in December. ---(2001). Text of The Great Leap Forward: An Inevitable Need of History. A Political document approved by the Second National Convention of the then CPN (Maoist) in February. Retrieved from http://www.bannedthought.net/ Nepal/UCPNM-Docs/2001/GreatLeapForward-2001.pdf on 24 June 2017.

---(2005). Rajnaitika Awama Sangathanatmak Prastawa (Political and Organizational Proposal). A document adopted by the extended CC Meeting (Chungwang Plenum) in October.

--(2006). "Politics in Nepal is Like a Frozen Pond", interview by Jhalak Subedi and Purna Basnet, translated from Neplai by Hari Roka, Bela Malik and Thomas Mathew. in Colin Gonsalves and Mihir Desai (eds.). Combat Law, 5: 4 (September-October 2006), pp. 16-20. Retrieved from https://docs. google.com/viewerng/viewer?url=http://combatlaw.org/wp-content/uploads/ combatlaw_volume5_2006/September-October-2006_nepal.pdf\&hl on 02 June 2017.

--(2008). Text of the Political Document. Presented in Kharipati National Convention of the CPN (Maoist) on 17-26 November 2008.

--(2010). Text of the Political Document. Presented at Palungtar Plenum on 21-28 November in Gorkha district.

- 23 - Journal of Political Science, Volume XVIII, 2018 
(2011) Text of Political Document. Presented in Standing Committee meeting of the UCPN (Maoist) in 02 April.

-(2013). Text Political Document. Adopted by Seventh General Convention at Hetuada on 2-7, February 2013.

-(1995). Text ofPlan for Historical Initiation of People's War. Adocumentadopted by the thenCPN (Maoist) CC Meeting in September.

Rawal, B. (1988). Nepalma Samyawadi Andolan: Udhbav Ra Bikash (The Communist Movement in Nepal: Origin and Development). Kathmandu: Saman Prakasan. (1991[2047]). Nepalma Samyawadi Andolan: Udhbav Ra Bikash (The Communist Movement in Nepal: Origin and Development). Kathmandu: Pairabi Prakashan.

Refugee Review Tribunal. (n. a.). Retrieved from https://www.ecoi.net/file upload/1997 1294644299 npl35563.pdf on 25 August 2017.

Republica, 21 December 2010.

Sigdel, I. M. (2008). Nepal: CPN (Maoist) National Convention Beginning the "Great Debate"; Split Avoided. Retrieved fromhttp://links.org.au/node/786on 26 August 2017.

South Asia Terrorism Portal (n. a.). Retrieved from http://www.satp.org/satporgtp/ sair/Archives/6_23.htm on 25 August 2017.

Subedi, J. (2017). "Transformation of the Maoists From Revolutionaries to Reformists? Translated from the original Nepali by Manesh Shrestha. In Deepak Thapa and Alexander Ramsbotham (eds.) Accord, an International Review of Peace Initiative, 26 (2017), pp. 37-40. Retrieved from http:// www.c-r.org/downloads/Accord-26-Nepal-WEB 0.pdf on 02 June 2017.

Tarun Weekly, 4 June 2001.

The Washington Times, 14 December 2002. Retrieved from http://www. washingtontimes.com/news/2002/dec/14/20021214-105150-2928r/ on 21 August 2017.

Varadarajan, S. (2006). "Exclusive Interview with Prachanda, Maoist Leader". The Hindu, 8-10 February 2006.

Washington Post, 22 November 2006. "Nepal's Premier, Rebel Leader Declare End to Civil War”. Retrieved from http://www.washingtonpost.com/wp-dyn/content/ article/2006/11/21/AR2006112101173.html on 01 August 2017. 


\title{
Changing Dynamics of Nepalese Foreign Policy: Patterns and Trends
}

\author{
Bhim Nath Baral
}

\begin{abstract}
After the unification of many tiny states into a single and unified state, the foundation of Nepalese foreign policy was coined by brave, visionary and nationalist king Prithivi Narayan Shah. On the basis of geo-reality, his foreign policy based on non-alignment and neutrality is still relevant. But the subsequent rulers could not maintain their foreign policy images. The trend of changing foreign policy tilt with every change in regime in general and leader in particular created difficulty in foreign policy making. The geo-strategic location of the country on the one hand and continuous political instability in the country on the other always created threat for its survival. The geographical proximity of two Asian powers and their security concern further added more threat upon our independence. All these conditions have played influencing role in the determination of foreign policy choices. Since, Nepal is in advantageous position to benefit from India and China, after a long transition, the newly elected government has almost single choice to act as a balance of local, regional and global interest. So the main objective of this article is to analyze the patterns and trends of Nepalese foreign policy choices. Secondary sources of data are used to achieve the objectives.
\end{abstract}

Keywords: Equidistance, equi-proximity, geo-politics, non-alignment, zone of peace.

\section{Introduction}

Modern world is characterized by interdependency nature. Here the states are the major units of international system who always take part in interaction with the aim to protect their interest. In this age of growing interdependence no nation can remain in 
isolation. So, there are always reasons for interactions among the actors of world community to form international processes. Their interactions are best reflected on the policies adopted by the state towards other states. These policies are generally known as foreign policies which involve regulating and conducting external relations of the state with respect to other in the international scenario. Like internal and domestic politics, a state should pay special attention to the careful formulation and successful execution of foreign policy. It is only through the adoption of sound foreign policy and its effective implementation that a nation's sovereignty is preserved, international dignity is enhanced and the national interest promoted (Thapa, 2014:1). A careful foreign policy enhances a nation's power and prestige in the comity of nations. Achievement in foreign policy also increases the government's credibility in the eyes of public internally as well as externally (Malhotra, 2014:156). So foreign policy has been a very sensitive issue for every policy maker. A nation's foreign policy is formulated on the basis of its position vis-à-vis of the states in the international system. Since it is too hard for a country to remain in isolation in the present day world, it must follow the established pattern of relationship with other and act accordingly. A state must set up the long term and short term objectives clearly to maximize the benefits it can acquire from the established system (Khanal, 2009:98). In such situations, it becomes the primary responsibility of every state to adopt the adequate policy to serve their interest. Though the interest of the state may vary from time to time, it can best be preserved by adopting reasonable foreign policy (Baral, 2072:95). But all the states are not equally found capable in making sound foreign policy in regard to protect and promote their interest. Basically, the small powers like Nepal are unable to make adequate choice in their foreign policy matter. To a large 
extent, Nepal has been struggling hard for its survival in the anarchic international system where there is no super sovereign authority over state to maintain global order and enforce rule (Dahal, 2011:31). It became a compulsive necessity for Nepal to make various choices in foreign policy matter to survive in several challenging modes of history. Through out its history, Nepal has always been cautious when it comes to dealing with both of its immediate neighbours (Republica, 2016:6). Even after the advent of democracy to till date, Nepalese foreign policy choice has remained changing. The tendency to change foreign policy tilt with every change in government has posed difficulty for Nepal to maintain internal cohesion and external adaptation (Dahal, 2011:1). However, Nepal has never remained under the colony of any power country in its history. Our ancestors could preserve the survival of the nation even in the critical days of nation building.

So, the questions automatically arise that what were the major pattern and trend of Nepalese foreign policy? Why different choices were made in foreign policy matter? and how it could be possible for Nepal to preserve the independent identify of the nation? This article aims to achieve the answer of the questions.

\section{Objectives of the Study}

The principal objective of this article is to analyze the changing dynamics of Nepalese foreign policy. Besides this, the specific objectives are to present a brief account of the evolution and development of Nepalese foreign policy and to assess the changing pattern and trends of Nepalese foreign policy.

\section{Methodology}

In spite of its small strength, Nepal was able to maintain its existence during its early stage of nation building. It was possible 
through the adoption of adequate foreign policy. But along with the passage of time, foreign policy making and its execution has become a challenging task. So, this article is mainly related with the changing patterns and trends of Nepalese foreign policy in different modes of history. So, the study is made on descriptive and analytical design. The required data is acquired from secondary sources i.e. books, journals, newspapers, documents and previous research works as well. Library method is used. The nature of data is qualitative.

\section{Concept of Foreign Policy}

International system is composed with different actors. There is continuous interaction among the various actors of global system for the purpose of protecting and promoting their interest. Every actor and their behavior is determined by the fundamental instinct i.e. national interest. The way of dealing or the pattern of interaction of an actor with the other actor is mostly influenced by the core thinking of national interest. By taking this fact into mind, every actor is guided by certain policy. Such policy pursued by a nation while dealing with the other is generally known as foreign policy.

Foreign policy has been defined by several scholars and thinkers on their own accord. It refers to the ways in which the central governments of sovereign states relate to each other and to the global system in order to achieve various goals or objectives (Jaiswal, 2016:2). A foreign policy is generally designed to help, protect and promote country's national interests, security, economic prosperity and independent international image. According to Robert Jackson and Georg Soresen (2013:252) "foreign policy is the management of external relations and activities of nation states, as distinguished from their domestic policies. It involves goals, strategies, measures, methods, 
guidelines, directives understandings, agreement and so on, by which national governments conduct international relations with each other and with international organization and nongovernmental actors". "Foreign policy", as Schleicher views "refers to the actions (including the words) of government officials to influence human behavior beyond the jurisdiction of their own state. In a broader sense, foreign policy includes the objective, plans and actions taken by a state related to its external relationship" (quoted, Malhotra, 2014:156). "Foreign policy", according to Padelfordand Lincoln, "is the key element in the process by which a state translates its broadly conceived goals and interests into concrete courses of action to attain those objectives and preserve its interests "(Quoted, Thapa, 2014:1-2). In the words of Rodee "Foreign policy involves the formulation and implementation of a group of principles which shape the behavior pattern of a state while negotiating with other states to protect or further its vital interests (Quoted in Dahal, 2009:21).

On the whole, it can be said that foreign policy is the instrument to promote national interest. It is the policy pursued by a state incourse of dealing with international community. It is the guideline on the basis of which a state conducts its foreign relations and behaves at international level.

Besides the above definition, foreign policy analysis is based on a broader context of academic knowledge. The concept is determined by several theories. Though theory and policy does not necessarily lead to any one clear policy option, in most cases there will be several different options. Even so, the choice of theory how policy makers view the world is likely to affect the choice of policy (Jackson and Sorensen, 2013:252). However, there are two broad theories with different values emphasizes in the formulation of policy i.e. realism and liberalism. Realism is 
a school of thought that explains international relations in terms of power (Goldstein and Pevehouse, 2008:43). It is based on pessimistic view of human natural. Human are self interested and egoistic. The relations are conflictive and may always lead to war and foreign policy decision making is influenced by the value of national security and state survival (Jackson and Sorensen, 2013:312). Realism is based on a view of the individual as primarily selfish and power seeking. Individuals are organized in states, each of which acts in a unitary ovary in pursuit of its own national interest (Mingst, 2004:66). So, the main concern of foreign policy makers is to manage their insecurity.

The liberal approach, on the other hand, emphasizes the great potential for human progress in modern civil society and the capitalist economy, both of which can flourish in states which guarantee individual liberty. Freedom and democracy are the core values of relations of this school of thought. The liberalists are more optimistic about the prospects for peace and see the rules of international relations as slowly, incrementally evolving through time and potentially becoming more and more peaceful (Goldstein and Pevehouse, 2008:84). This evolution results primarily from the gradual build up of international organization and mutual cooperation and secondarily from changes in norms and public opinion.

The above theories are very relevant in the analysis of the patterns and trends of Nepalese foreign policy. Nepal's geostrategic position sometimes overrides the basic assumptions of the established theories. From realistic point of view, Nepal has been struggling hard for its survival since the very beginning of nation building. Preservation of national independence has long been the most formidable problem of Nepalese foreign 
policy. According to liberalists, "relations between liberal states will be collaborative and cooperative" (Jackson and Soresen, 2013:309). But it could not be realized while making analysis of foreign policy of Nepal and its immediate neighbours. The specific policies pursued by the various governments may have varied from time to time in accordance with changing circumstances, but certain basic considerations have delimited both the style and the content of their responses to external influence and challenge (Rose: 1971:277).

No doubt, a nation formulates its foreign policy keeping in view of its various national interests and objectives. For this, general, internal and external determinants also play varying degree of role due to which foreign policy takes different terms and shape in different countries. The view of policymakers a country's approach towards outside world is likely to affect the choice of policy. Policy of isolation, policy of special relation, policy of equidistance, policy of zone of peace, policy of nonalignment and the policy of equi-proximity have remained the major foreign policy choices of Nepal. The trend and pattern of changing foreign policy is discussed in the following points:

\section{Evolution of Nepal's Foreign Policy}

Nepal, as a landlocked country, is strategically located between two very strong and powerful countries of Asia, China and India. Due to the unique geographical location of the country, the rulers have remained cautious from the very beginning regarding relations with foreigners particularly the two immediate neighbors. This fact is reflected very well in Prithvi Narayan Shah's teaching (Divya Upadesh). It was during the second half of eighteenth century that, the brave, visionary and nationalist king Prithvi Narayan Shah provided not only the basis for modern Nepal's foreign and security policies but has 
also contributed in shaping its worldview (Khanal, 2009:96). He stated that Nepal is yam between two boulders. He further said that great friendship should be maintained with the Chinese emperor. Friendship should also be maintained with the southern seas (The British) (Aryal andet. al., 2011:15). His suggestion was not to engage in an offensive attack, fighting should be done a defensive basis. If it is found difficult to resist in the fight then even means of persuasion, tact and deceit should be employed (Acharya, 2070:13).

\section{A. Independent Foreign Policy}

As Prithvi Narayan Shah was fully aware about geostrategic reality of Nepal and had suggested his followers to adopt independent foreign policy. This spirit can be vividly seen in his 'DibyaUpadesh'. But the succeeding rulers could not maintain independent and non-aligned foreign policy as Nepal involved in wars with Tibet and British India in 1792 and 1814 respectively (Khanal, 2009:100). As a result, Nepal's boundary was more or less fixed. Basically, the Sugauli Treaty (1816) had limited Nepal's external relations and British India remained the only focus of Nepal's external dealings. The crisis in foreign policy and its subsequent consequences could be seen right from the Sugauli Treaty.

\section{B. Policy of Isolation}

British India-centric foreign policy had introduced in Nepal after Sugauli Treaty. Jung Bahadur's rise in power after KotParva on the night of September 14, 1846 established Rana rule and resulted in a major redefinition of Nepal's foreign policy (Lamsal, 2017:4). A practical Politician like Jung Bahadur was also aware of the decline of Chinese power and it was not in a position or willing to challenge the British power in the Himalayan area and he adopted British -centric foreign policy Changing Dynamics... Bhim Nath Baral - 32 - 
(Rose, 1971:106) . The chief aim of the Rana prime ministers, including that of Jung Bahadur, had been to keep up good relation with the United Kingdom. As a result, Nepal in those days looked at the international problems from the British point of view (Khanal, 2000:1). Nepalese foreign policy was given additional emphasis with Jung Bahadur's visit to England as the visit strengthened his view that British rule in India was not going to be easily overthrown and that the confrontation with the British would be something like playing with fire. The ties of relation became more close when Nepal assisted the British ruler to suppress Sipoy Mutiny of 1857 (Thapa: 2016:14). Jung Bahadur's visit to Europe via-Britain, contribution of Nepalese army in world wars in support to Britain also supported to make the relation more close. All these factors kept Nepal in isolation from the rest of the world. It is true that the policy of isolation would eventually also prove to be beneficial to the continuation of Rana regime and to serve the country from British usurpation as well (Sharma, 2006:15). Finally, during Rana days Nepal was thus isolated from the current of world opinion, parochial conservatism, distrust and doubt- all these elements cast their weight on the foreign policy in the past (Khanal, 2000:2).

\section{Policy of Special Relation}

The political change of 1950 brought 104 years old Rana oligarchy into an end. The newly introduced democratic system paved new pattern in foreign policy outlook. However, Nepal's external relations during king Tribhuwan's rule were dominated by India. The two countries were described as having had "special relation" with each other (Muni, 2016:59). This relation was mainly confined with our southern neighbor. Nepal's relation with China was rarely cared. There were various factors that accounted for "Special Relations" between 
Nepal and India. The tie of special relation between Rana ruler and British India was rooted during Rana rule. After British departure from sub-continent, no substantial changes occurred in the situation. Signing of tripartite agreement providing for the British recurrent of the Gurkha soldiers in India, peace and friendship treaty of 1950, extradition treaty with India in 1953 etc. were the major events to have special relation with India (K.C. 2072: 1-22). It was also stated that the peace and friendship treaty was concluded at a time when Nepal feared a Chinese threat, particularly after the Chinese occupation of Tibet (Saran, 2017:153). It was also in practice that Indian ambassaders to Nepal had to attain the cabinet meeting. Govinda Narayan, the home secretary of Utter Pradesh, was deployed as the special secretary of king Tribhuwan (K.C., 2072:14) Besides these, India's role in Anti Rana movement and familiarity of Nepalese freedom fighters with Indian soil were also responsible for the situation. When we talk about special relation, the matter of dependency, special direction and interest came upon the small states (Shahi, 2073:133). All these situations created India's open influence in Nepalese foreign policy.

\section{Non-aligned Foreign Policy}

The devastating Second World War brought sea changes in world politics. The pre war friends started to form their own alliances just after the post war international relations. Nepal also witnessed a new chapter in its foreign policy. An important political development that contributed to the new state of affairs was king Mahendra's coming to power. Two outstanding events took immediately after the accession of king Mahendra to the throne on March 13, 1955. Nepal's admission to the united Nations and the establishment of diplomatic relations with the communist Chinese government (Rose, 1971:208). The year 
1955 was to be the most significant year in Nepal's foreign policy. Nepal's participation in Afro-Asian conference held at Bandung later paved the way for Nepal's non-aligned foreign policy. It was Bandung conference which provided the bases for nonalignment movement in the form of principles of Panchasheel. From that day onwards,non alignment has remained as the basic guideline of Nepal's foreign policy. Non alignment was a historic necessity for Nepal and as well as others which would create opportunities for the peaceful political development of nations and above all, in a non-military dimension, suggest a middle path before rival pressures (Khanal, 2000:425). Further, It was compulsive necessity for Nepal to adopt this policy to survive in critical days of cold war politics and its own geostrategic location as well.

\section{E. Policy of Zone of Peace}

The most important and original strategic policy adopted by Nepal in order to project its changing security was the proposal of Zone of Peace. When king Birendra ascended the throne of Nepal, he introduced new foreign policy decision to declare Nepal as a 'Zone of Peace'. The concept was first mooted in 1973 at the non-aligned summit held at Algiers. It was formally forwarded at the coronation ceremony of king Birendra held in Kathmandu on 25 February 1975 (Sharma 2006:239). The main theme of declaring Nepal as "Zone of Peace" was to maintain neutrality in all possible regional conflicts and also ensure domestic political stability and economic development (Muni, 2016:234-235). The events in the neighbourhood were threatening the security of the nations and world political situation was also in critical mode. India's assertion of its position following its policy tilt to the Soviet Union in 1971, active role in the division of Pakistan and emergence of Bangladesh, annexation of Sikkim, a tiny 
Himalayan state close to Nepal and nuclear test inspired Nepal to innovate a new policy initiative to be declared Nepal as a "Zone of Peace" (Dahal 2011:41). Nepal also faced difficulties during this time due to Khampa incident and other domestic problems (Baral, 2072:97). The proposal was mostly based on the spirit of nonalignment and principles of Panchasheel. So, it received overwhelming support from 116 countries but India has not yet welcomed by thinking that Nepal had certain other objectives (Srivastav, 2016:41).

\section{F. Policy of Equidistance/ Equi-proximity}

Nepal's foreign policy has remained a difficult, serious and sensitive subject owing to its geopolitical and underdevelopment. In course of dealing with foreign policy matters, Nepal's geopolitical and geostrategic location has obligated it to adopt a balance policy with its immediate neighbors. Nepalese foreign policy was under the dominance of India till mid 1950s. Nepal's entry into global environment was opened after its membership in UNO in 1955. The then king Mahendra adopted the policy of maintaining equal relation between India and China. The one sided relation now started balancing with the construction of Araniko Highway despite India's objection (Thapa, 2016:19). Nepal's strong commitment on non-aligned movement and considering the principles of Panchasheelas the bases of Nepalese foreign policy became the steps towards maintaining equidistance foreign policy. Mahendra also shaped Nepalese foreign policy to suit the times by diversifying and establishing diplomatic and commercial relations with different countries of the world.

During the Panchayat Period, Nepal had emphasized the policy of equidistance regarding its relation with the two immediate neighbours. After 1990, the concept of equi-proximity was 
introduced to justify the closeness with Nepalese power centers basically with immediate neighbours. According to Dhruba Kumar as quoted by Dahal (2009:34-35) the term "equiproximity" as "a conception guaranteeing a balanced relationship with both India and China. Sovereign equality remains central to this proposition. In so doing, Nepal should advisedly undertake an effort to review all the previous treaties and discard the ones that had proved unfavourable to the country's national interests. The thrust of the argument conclusively points towards ending the special relationship with India, which restricts Nepal's freedom to maintain a meaningful relation with China. Nowhere has this feeling been reflected more correctly in recent memory than in the case of Chinese arms versus Indian blockade." Compared to the diplomacy of equidistance, Nepal's success in the diplomacy of "equi-proximity" which is a constructive policy based on mutual trust, equal benefit and cooperation.

The question of "balanced relation" is equally vital in Nepalese foreign policy determination. Many Indian foreign policy makers stressed India's special relationship with Nepal and became and highly objectionable of Nepal's policy of balanced relationship as both are closed in terms of cultural, economic, geographic and social conditions (Singh and Shah, 2016:56). The issue of balanced relation always remained a subject of debate. Formulation of foreign policy on the party line has created more fundamental issues. The leftist government is often blamed for following 'pro-Chinese policy' whereas the rightist or centrist government follow a 'pro-India policy'. But it is the geo-political reality for any government of Nepal not to be either 'pro-Chinese' or 'pro-Indian'. So, equi-proximity should be maintained in dealing with our immediate neighbours. However, Nepal has remained neutral in the conflict between India and China.Related to Doklam issue, in June 2017, Nepal had made 
it clear that it will stay neutral in the latest India China standoff, and it wants this issue to be resolved peacefully. Nepal had also remained neutral in Indo-China war of 1962.

\section{G. Nepal and Trilateral Cooperation}

Although, globalization has created inter-dependency and countries are unable to exist and develop in isolation, still the politics of power and hegemony discourages the interest of small powers on an equal footing. Nepal has been experiencing the direct impact of enmity, cooperation and competition of India and china. Their relation is full of enmity, cooperative and competitive from the point of view of border, trade and strategic issues (khanal,2073:286). The recent case of LipuLekh has raised the questions regarding our position. While reaching bilateral understanding during the Indian Prime minister Narendra Modi's visit to Beijing in May 2015, the Chinese President $\mathrm{Xi}$ Jinping and Modi were reported to have agreed to use this corridor for their interest (Baral;2016:13). So, the significant question then is: can there be a balanced trilateral relationship between the three countries? However, the issue of trilateralism is a compulsive necessity for all Nepal, China and India because of political, strategic and geo-realities.

In the recent years, both the leaders of India and China have focused on development and economic prosperity. They have made massive progress in road, railway and maritime connectivity too. $\mathrm{Xi}$ Jinping's ambitious project of OBOR (One Belt One Road) has the aim to be connected with about 60 countries of Asia, Africa and Europe. President's vision of creating a 'community of common destiny' through 'Go West' and 'Peripheral Strategy'(Subedi, 2016:41)have extended a kind of significant advancement of India in the field of Science and technology and its 'Neighbourhood First' Policy can be fruitful 
for our prosperity. If these policies are honestly enforced, the concept of trilateralism can be materialized.

But it does not mean that our immediate neighbours will put aside their security concern. China is always cautious about whether Nepali land might be used for anti-China element. China is more concerned about Tibet issue when it comes to dealing with Nepal. The border dispute, the Tibetan refugee issue and china's strategic relation with Pakistan continue to be irritants in ChinaIndia relations (Baral,2016:11-25). India is equally worried about growing Chinese influence in Nepalese Politics. India is not happy with Chinese investment in infrastructure and energy in Nepal. Besides these, the open border borne problems like circulation of fake currency, increasement in criminal activities, rising terrorists attack, illegal trade, drug and human trafficking, etc always create tension between two countries. Growing antiIndian Sentiment in Nepal has also created more problems. However, Nepal is committed to ensure its neighbours about their security concern by not allowing the Nepalese land for the activities against them.

\section{H. Constitutional Provision}

Constitution is the major guiding document of the overall affairs of the nation. As the supreme law, the Constitution of Nepal 2072 has made clear provision about Nepalese foreign Policy. The latest constitution has not made any substantial changes regarding foreign policy. However, part four of the constitution has made the provision of directive principles, policies and obligations of the state. It is mentioned that the state shall direct its international relations towards enhancing the dignity of the nation in the world community by maintaining international relations on the basis of sovereign equality, while safeguarding the freedom, sovereignty, territorial integrity and independence 
and national interest of Nepal(article 50(4). Likewise, under the topics 'Policies of States' the state has the aim to conduct an independent foreign policy based on the Charter of the United Nations, non-alignment, Principles of Panchasheel, International law and the norms of the world peace taking into consideration of the interest of the nation. While remaining active in safeguarding the sovereignty territorial integrity, independence and national interest of Nepal (article 51(m(1)). The additional provision made in the constitution is that the government will pursue the policy to review treaties concluded in the past and make treaties, agreements based on equality and mutual interest (article 51(m)2). There have been several changes in guidelines of foreign policy are almost same. With the change in situation it is necessary to rethink about Nepalese foreign policy. Basically it is the demand of the general public and political parties of Nepal to rethink about the relation with the southern neighbour.

\section{Formation of Eminent Persons Group (EPG)}

Nepal and India are so well bounded by various cultural, religion, social, economic and geographical ties. But the relation has remained paradoxical as commented by India diplomat, Shyam Saran (2017:149). Basically, Anti India sentiment is growing in Nepal especially after Indian blockade of 2015. It is a subject of debate regarding the treaties signed between the two countries in different times. By realizing the fact, a joint mechanism with a group of foreign policy expert called Eminent Persons Group (EPG) has formed. The mandate that was given to EPG following the meeting between (then) Prime Minister K.P. Oli and Prime Minister Narendra Modi on 20 February, 2016 included taking a serious look at a possible review of Friendship treaty which was concluded decades ago. The EPG has formed to look into the totality of Nepal- India relation from independent,. non- 
governmental perspective and suggest measures to further expand and consolidate the close and multifaceted relations between the two governments. The EPG group from Nepali side is headed by Bhekh Bahadur Thapa, former foreign minister of Nepal with Nilambar Acharya, Dr Rajan Bhattarai and Suryanath Upadhaya as the members. Likewise, Bhagat Singh Koshiyari, Leader of Indian ruling party, is heading Indian side with Dr. Mahendra P.Lama, Prof B. C.Upreti and Jayanta Prasad as the members(the Kathmandu Post, 6 July, 2016;1). The eight members group have been entrusted with the responsibility of putting together a mutually agreed document within two years to suggest ways to strengthen bilateral ties in view of evolving regional dynamics and world order. The EPG has the main aim to revise the bilateral agreements and arrangements. Generally, it has the mandate to take into five broad areas of Nepal-India ties i.e. political relation, government to government ties, development cooperation, economic exchanges and social and cultural relationship. Hope that its recommendations will be fruitful in strengthening the relation between these two closed neighbours.

\section{J. Nepal and the World Community}

Nepal's entry into international community formally opened only after its membership of the UNO in 1955. Further, Nepal also became the temporary member of Security Council of the UNO twice (1969-1970 and 1988-1989). Nepal is one of the founder members of NAM which formally initiated from 1961. Nepal's contribution in the establishment of SAARC in 1985 and establishment of SAARC Secretariat in Kathmandu has enhanced its prestige. Nepal's involvement in BIMSTEC (Bay of Bengal Initiatives for Multi-sectoral Technical and Economic cooperation) in 31 July, 2004 has widened its image in the world 
community. Currently, Nepal is chairing SAARC and BIMSIEC but Nepal's failure to organize their summits has raised many questions in its ability to regulate foreign policy.

\section{Conclusion}

From the very beginning of the formulation of Nepal's foreign policy the founding ruler Prithivi Narayan Shah had realized the geographical reality and recommended very cautious relations with them. After his demise, neither his successors could fully realized the actual situation nor could maintain national unity. In such situation, Nepalese foreign policy could not catch the fundamental shape. It passed through different patterns and the situations drastically brought substantial changes in foreign policy outlook. Neutral and non-aligned foreign policy, policy of isolation, era of special relation, equidistance policy, policy of zone of peace, non-aligned foreign policy, etc. were chosen in different periods of history. Whoever became the ruler, their main intention of making certain foreign policy was to sustain their regime. Even after the restoration of democracy, foreign policy choice could not go beyond party line. Whenever the ruler failed to manage internal affairs and tried to divert internal political conflict to the external affairs, they have invited trouble. The situation even put serious limitations to the country's pursuit of independent foreign policy.

Finally, after a long struggle with many ups and downs, political transition has somehow ended. The parties and general public have single fold demand for economic prosperity. In such condition, our immediate neighbours can be the decisive factors to achieve economic soundness through the transfer of aid/ investment, technology and market as well. It needs careful balance of own structure by giving proper attention in the management of their interest. We should make Nepal as a bridge 
between two emerging economies. We further need to maintain triangular relationship by action as a bridge between the two rising powers and play an active role in the establishment of trilateral cooperative ventures. The relation with one neighbour can't be taken at the cost of another. Our foreign policy should address the fragile image as one of the poorest and conflict prone state and its gradual erosion of international acceptability. Realizing all these factors so essential for the existence of Nepal, a comprehensive consensus should be built on the foundation of foreign policy through internal solidarity and it should be taken into operation.

\section{References}

Acharya, Jayraj (2070 B.S.). Nepalko Rastriyata Ra Pararastra Niti,

Vichar Prabaha, Versa 2, Anka 2, Pokhara: Prajatantrik Vichar Samaj, Pokhara.

Aryal Dornath, Ram Prasad Subedi and Surendra Thapa (2011).

Diplomatic Dealings. (fourth edition): Kathmandu: Apex Educational Academy.

Baral, Bhimnath (2072 B.S.). Foreign Policy of Nepal: Bases and Challenges in Legal Eye Kaski, Nepal Democratic Lawyers Association, District Committee, Kaski.

Dahal, Devraj (2011). The Art of Survival: Policy Choices for Nepal in Dhaulagiri Journal of Sociology and Anthropology. Vol. 5. Dahal Ramkumar (2009). Challenges in the formulation of foreign Policy for Nepal in Nepalese Foreign Policy at the crossroads.

Edited by Sushil Raj Pandey and Pushpa Adhikari, Kathmandu: Sangam Institute.

Dibya Upadesh (2054 B.S.). His Majesty the Government, Ministry of Youth, Spot and Culture. Department of Archaeology.

Goldstein, Joshua S. And Jon C. Pevehouse (2009). International Relations (Eight Edition). Dorling Kindersley India Pvt. Ltd, 
PEARSON.

Hamal, Yagya Bahadur (2014). Ecology of Nepal's Foreign Policy. Kathmandu: Nepal Centre for Development and Policy Studies Pvt. Ltd. (CEDEP) Nepal.

Jackson, Robert and Georg Sorensen (2013). Introduction to International Relations: Theories and Approaches. Fifth Edition: Oxford University Press.

Jaiswal, Pramod (2016). Nepal's Foreign Policy and strategic Significance in Nepal's Foreign Policy and Her Neighbours. Edited by Pramod Jaiswal and Geeta Kochhar, Delhi: Smt Neelam Batra, GB Books Publishers and Distributers.

K.C. Surendra (2072 B.S.). Nepalko Bharat Niti Tatha SandhiSamjhautaharu in Nepal-Bharat Ra Chin Sandhi Samikshyatmak Vivechana. Kathmandu: Madhuvan Prakashan.

Kantipur National Daily, 8 August, 2017.

Khanal, Gopal (2073 B.S.). Bhurajniti, Kathmandu: Phoenix Books. Khanal, Rabindra (2009). Donor Community and Nepal's Foreign Policy in Nepalese Foreign Policy at the Crossroads. Edited by Sushil Raj Pandey and Pushpa Adhikari, Kathmandu: Sangam Institute.

Khanal, Y.N. (2000). Nepal's non Isolationist Foreign Policy. Kathmandu: Satyal Publications.

Lamsal, Yubanath (2017). Jung Bahadur's Foreign Policy in The Rising Nepal, March 7, 2017.

Malhotra, Vinay Kumar (2014). International Relations (Fourth Revised and Enlarged Edition).New Delhi: Anmol Publications Pvt. Ltd.

Morganthau, Hans J. (1997). Politics Among Nations: The struggle for Power and Peace (Sixth Edition). New Delhi: Kalyani Publishers. Muni, S. D. (2016). Foreign Policy of Nepal. New Delhi: Adroit Publishers.

Palmer, Norman D. and Perkins Howard C. (2015). International 
Relations (Third Revised Edition). New Delhi: AITBS Publishers, India.

Republica, Nov. 2016, Vol. VII, No. 163 P. 6 (Editorial).

Rose, Leo E.(1971). Nepal Strategy for survival. London: University of California Press.

Saran, Shyam (2017). How India Sees the World. New Delhi: Juggernaut Books.

Shahi, Yogendra (2073 B.S.). Nepal Bharat Sambandha: VisheshHoina, Ashal Sambandha Ko Awashyakata in Nepal Bharat Sambandha: Bigat Bartamanra Bhavishya. Edited by Bijaya Kumar Poudel. Kathmandu, Milestone Prakashan Tatha Prasharan Ltd.

Sharma,Jagadish (2006). Nepal: Struggle for Existence. Kathmandu: Comm INC ICT Private Ltd.

Singh, Bawa and Shah, Shabaz Hussain (2016). Nepal's Equidistance policyTowards India and China: Exploring the Shifting Paradigm in the Post-Monarchial Era in Nepal's Foreign Policy and Her Neighbours. Edited by Pramod Jaiswal and Geeta Kochhar, Delhi: Smt Neelam Batra, GB Books Publishers and Distributors. Srivastav, Vivek Kumar (2016). Nepal's Foreign Policy in Quest of Identity in Nepal's Foreign Policy and Her Neighbours. Edited by Pramod Jaiswal and Geeta Kochhar, Delhi: Smt Neelam Batra, GB Books Publishers and Distributors.

The Constitution of Nepal (2072 B.S.). Government of Nepal, Ministry of Law, Justice, Constituent Assembly and Parliamentary Affairs, Law Book Management Committee.

The Kathmandu Post, 6 July, 2016. 


\title{
Foreign Relation of Nepal with China and India
}

\section{Girdhari Dahal}

\begin{abstract}
Nepal is sandwiched between two giant economic and politically powerful nations - China and India. Due to its geographical proximity and historically long multi-faceted linkages to China and India, Nepal's foreign policy with China and India is not distinctly independent but is mutually interdependent. Nepal's foreign policy has always prioritized maintaining balanced relation with these two nations for safeguarding its national interests, integrity and independence. In practice, Nepal has observed friendly and cordial relation with China while the relation with India has been both friendly and hostile. Nepal is firmly committed to 'One China Policy' and had just signed OBOR (One Belt One Road) and respects India's national independence and integrity. China has shown respect to Nepal's sovereignty and has not interfered in Nepal's internal issues while India has been seen trying to influence Nepal's internal politics. The main objective of this paper is to explore the foreign relation of Nepal with, China and India. This paper makes a brief description and analysis of Nepal's foreign policy, political and economic dynamics of these relations, and new developments in Nepal-China and Nepal-India relation based on secondary sources. Election of federal, provincial and local level was held after the declaration of new constitution. Nepal's new priority in foreign relation should be economic prosperity. So, Nepal, China and India must reach a new consensus to re-build strong
\end{abstract}


economic ties for mutual benefit of all.

Keywords: Affair, landlocked, non-alignment, diplomatic relation

\section{Introduction}

Nepal is a landlocked country. It is located between two giant economic nations China and India. The northern border of Nepal, which is mostly mountainous, is connected with China while southern (which is mostly plain), eastern and western border of Nepal is connected with India. The Constitution of Nepal (2015) has outlined the directive principles, policies and obligations of the State regarding its foreign policy. The foreign policy of Nepal is guided by the abiding faith in the United Nations and policy of non-alignment, mutual respect for each other's territorial integrity and sovereignty, non-interference in each other's internal affairs, respect for mutual equality, non-aggression and the peaceful settlement of disputes, and cooperation for mutual benefit as per the guiding principles of our foreign policy (Shrestha, 2018). Although Nepal established a diplomatic relation with India and China respectively in 13th June, 1947 and 1st August 1955 (MOFA, 2017), Nepal has a relation with China and India since their existence. Nepal's foreign relations with China and India have evolved through different events, stages and periods in history. So, Nepal has multitude of relations with these two neighboring nations- ranging from social, cultural, religious, geo-political, and economic to diplomatic relations. These relations have grown through different ups and downs, and transformed from simple, linear relation to complex, weired relations. At present, Nepal has established diplomatic relations with 155 nations (MOFA, 2017) but Nepal's foreign relations with China and India are much broader, wider, vital, and dynamic and feature special characteristics. After the declaration of new constitution and establishment of federalism in Nepal, Nepal's 
relation with China and India needs to be redefined and revised in the changed perspective and is sure to evolve from new dimension. The geographical location, size, natural resources, population and other physical features and environmental features influence a country and determine the political, military level of economic development and cultural characteristics of a nation (Bhattarai, 2005). So, at this scenario, it is worthwhile to discuss historical development of Nepal's foreign relation with China and India; different bilateral treaties with these nations; dynamics of these relations in Nepal's geo-politics, socioeconomy, and culture; and different issues related to this.

\section{Objectives and Methodology}

The general objective of this paper is to explore the foreign relation of Nepal with China and India. This paper makes a brief analysis of Nepal's foreign policy with China and India, political and economic dynamics of these relations and new developments in Nepal-China and Nepal-India relation based on secondary data.

\section{Review of Literature}

Constitutionally, foreign policy is to be guided by the principles of the United Nations Charter, non-alignment, Panchsheel (five principles of peaceful coexistence), international law and the value of world peace (Constitution of Nepal, 2015). In practice, Nepal's foreign policy has not been directed towards projecting influence internationally but towards preserving autonomy and addressing domestic economic and security issues.

Nepal's foreign relations in consonance with the policies and guidelines of Government of Nepal are made to protect Nepal's independence, sovereignty, territorial integrity, and enhance national interest abroad; to promote bilateral, regional and 
multilateral relations for the socio-economic development of the country, to promote friendly relations with all the countries of the world and particularly with its immediate neighbors, on the basis of sovereign equality, mutual respect, trust, goodwill and understanding to play an active role in the United Nations and other international organizations, in order to promote international peace, security and development to play a positive and meaningful role in the world (MOFA (2017). Because of its geographical proximity to and historical links with China and India, Nepal's foreign policy was focused mainly on maintaining close and friendly relations with these two countries and on safeguarding its national security and independence (Savada, 1991). The successful second pro-democracy movement, the country needs to examine its conduct of foreign policy in the context of those changes and formulate and adopt its foreign policy correspondingly (Bhattarai, 2013). With respect to all of its neighbors, Nepal has taken concrete steps over the past two years to promote goodwill and deep economic and social connectivity with India. But nationalist sentiments in all these countries often directed against India as the region's predominant power - will continue to present a challenge (Jaishankar, 2016). Nepal needs entering into treaties and agreements on the basis of equality and mutual interest, by reviewing past treaties.

\section{Nepal-China Relation}

Nepal and China share deep rooted and age old friendly relations with each other. The marriage of Nepalese Princess Bhrikuti Devi with the emperor of Tibet, Songtsan Gampo in 7th century (Chinese Buddhist Enclopedia), visit of Nepali craftsman Araniko to China in the 13th century and visits to Nepal by Chinese monks and scholars at different periods in history paved a solid foundation in the development of Nepal-China relation 
(Bhandari, 2017).

Nepal and China officially established diplomatic relation in 1955. At present, Nepal and China enjoys friendly and cordial relation by respecting each other's sovereignty, territorial integrity and independence. The Chinese Embassy to Nepal (2007) has characterized Nepal-China relations as based on "trust, equality and sincerity". It further adds;

The two countries never threat each other, harm each other or doubt each other; but always respect each other, believe each other and help each other. The Chinese Government and people firmly pursue the principle that a country is equal with others no matter how big or small it is. In the past 50 years, abiding by the Five Principles of Peaceful Coexistence, through equal dialogue, communication and coordination, China and Nepal have made excellent cooperation and achieved great accomplishments in bilateral political relations, regional affairs and international forums... China treats Nepal as its closest neighbor and best friend. We highly appreciate the strong support Nepal has given to us over the years on the questions of Taiwan and Tibet and other major issues related to China's sovereign rights and interests. (Chinese Embassy to Nepal, 2015)

Nepal has always shown strong commitment to 'One China Policy' and has never allowed its soil to be used for any hostile activities against China. China has also supported late king Birendra's proposal to declare Nepal as 'Peace Zone' and has never interfered with the internal affairs of Nepal and highly respected the road of development chosen by the Nepalese people (Chinese Embassy, 2007). China has been the good partner in Nepal's development endeavor. In this way, Nepal and China are enjoying good relations with each other. 


\section{Nepal-India Relation}

Nepal and India also share age-old and deep rooted relations with each other. Unlike China, there are more ups and downs in Nepal-India relations. Despite this bitter truth, Nepal-India relation is multi-faceted and it is basically characterized by an open border and a strong contact between people to people. In the past, Nepal and India had shared a very glorious and friendly relation which was basically founded on culture, religion and trade. Marriage of Nepalese Princess Sita with the prince of Ayodhya, Ram visit of Char Dham in India by Nepali Hindu pilgrimage; visit to Pashupatinath and Muktinath by Indian Hindu pilgrimage, and cross border marriage between Nepali and Indian nationals from ancient time till date are the history building blocks of Nepal-India relations.

Nepal and India officially established diplomatic relation in 1947. At present, Nepal-India relation is largely directed by 1950 India-Nepal Treaty of Peace and Friendship, which Nepalese side considers as unequal. India has greater- and unnatural- influence in Nepal's internal politics which is not liked by the Nepalese nationals. Although Nepal and India have reached the consensus to revise all the previous unfair treaties-especially 1950 IndiaNepal Treaty of Peace and Friendship, they are not finalized yet. There exists two contrasting relationship between Nepal and India. People to people relation are always good and stable while the government to government relation has many ups and down and is very volatile. There are some border disputes between Nepal and India which also make situation tense in the border area very often. Despite all these facts, Nepal is in the position to maintain good relation with India respecting each other's sovereignty, integrity and independence.

India's mindset towards Nepal can best be understood by 
the statements of Indian Embassy to Nepal (2015) on new constitution, promulgated by taking the support of more than two third majority of constituent assembly members, as:

Nepal's second Constituent Assembly promulgated a Constitution on 20 September 2015 amid protests by Madhes-based parties and other groups. The Government of India has expressed grave concern regarding the ongoing protests and has urged the Government of Nepal to make efforts to resolve all issues through a credible political dialogue.

This statement implies that India has their own concern and interests on Nepal's domestic issues. Nowadays the government Nepal and Indian have started to make intellectual response to review the 1950 treaties. After the application of new constitution in Nepal, situation has changed and left alliance has formed the government from the centre to the most local levels in Nepal government of Nepal. In this way, Nepal and India have both friendly and hostile relations between them.

\section{Result of China-Nepal Discussion}

\section{Assistance to Develop Nepal}

China has remained as one of the major donor countries for Nepal. Nepal and China first signed an agreement on economic aid in 1956. China has been providing financial and technical assistance to Nepal in the areas of infrastructure development, transportation, industrial development, health, education, hydro power development and so on. Some of the major projects built under Chinese assistance are: Arniko Highway, Prithvi Highway, Kathmandu Ring Road, Pokhara-Baglung Road, Syaphrubesi Rasuwagadhi Road Project, Bansbari Leather and Shoes Factory, Hetauda Cotton Textile Mills, Harisidhi Brick Factory, Bhrikuti 
Paper Mills, Lumbini Sugar Mills, Sunkoshi Hydroelectricity Plant, Pokhara Water Conservancy and Irrigation Project (Multipurpose), B.P. Koirala Memorial Cancer Hospital, Civil Service Hospital, National Ayurveda Research Centre Sports, Satdobato Sports Complex, City Hall in Kathmandu and Birendra International Convention Centre (MOF, 2014). Also, the ongoing projects under Chinese assistance include: Upper Trishuli Hydropower Project, Kathmandu Ring Road Improvement Project, Pokhara International Regional Airport, and National Armed Police Force Academy Project (MOF, 2014). With the signing of the Memorandum of Understanding on Cooperation under the one Belt and one Road Initiative on 12 May 2017 in Kathmandu between Nepal and China, new avenues for bilateral cooperation in the mutually agreed areas are expected to open (MOFA, 2017).

\section{Trade and Investment}

China is the second largest trading partner of Nepal. In 2015/16, total exports to China stood at US\$181 million with marginal increase from US\$179 million in the previous fiscal year. In contrast, import from China has been growing at the rate of 39 per cent per year. It rose from US\$421 million in fiscal year $2009 / 10$ to US $\$ 1,247$ million in fiscal year 2015/16. Although China has given zero tariff entry facility to over 8000 Nepali products that starts from 2009, Nepal exports only 370 products including noodles and agro products to China (MOFA, 2017).

China is the largest source of Foreign Direct Investment in Nepal. Chinese investors have shown intent to spend over $\$ 13.51$ billion in Nepal during the Nepal Investment Summit concluded in Kathmandu in March 2017 (The Kathamandu Post, 2017). 


\section{Tourism}

It will be the major boost to Nepal tourism sector of 150,000 Chinese tourists, by air visit Nepal in 2018 as expected, according to NTB. Nepal received a total of 104,664 Chinese tourists in 2017, according to Nepal's Department of Immigration. China is the second largest source of foreign tourist to Nepal. Over 1 lakh Chinese tourists visit Nepal annually. China has designated Nepal as the first tourist destination in South Asia for its people. The Government of Nepal has waived visa fees for the Chinese tourist effective from 1 January 2016 (Xinhua net, 2018).

\section{Recent Development in Nepal-China Relation}

One of the landmarks in Nepal-China relation was built when the then Prime Minister K.P. Oli signed Transit and Transport Agreement in his official visit to China in 2016. At present, Nepal and China are enjoying very friendly, broader and deeper relation followed by frequent exchange of high level officials' visit from both sides. Nepal and China have new tangent treaties for alternative point of view as well as one belt and one road initiative. In the recent years, the leaders of India and China have focused on development and economic prosperity. They have made significant advancement in road, railway and nautical connectivity. Xi Jinping's ambitious project of one belt one road has the aim to be connected with about 60 countries of Asia, Africa and Europe. President Xi Jinping has a vision of creating a 'community of common destiny' through 'Go West' and 'Peripheral Strategy'(Subedi, 2016) Nepal has also supported and agreed with this ambitious one belt one road project.

\section{India}

\section{Development Aids}

Nepal and India officially started economic cooperation in Foreign Relation... Girdhari Dahal - 54 - 
1951(MOF, 2014). India is providing broad spectrum financial and technical assistance in many projects in the past and at present. Some of the projects completed under Indian assistance are: Nepal's first six airports at Gauchar (1951), Simra, Janakpur, Bhairahawa, Pokhara and Biratnagar, Koshi Barrage, Devighat Hydropower and Irrigation Project, Janakpur-Jayanagar Railway's East -West Highway, B. P. Koirala Institute of Health Sciences, National Trauma Centre (MOF,2014). Currently, 36 intermediate and large projects such as construction of a National Police Academy at Panauti, Nepal Bharat Maitri Pashupati Dharmashala at Tilganga, and a Polytechnic at Hetauda are at various stages of implementation.

\section{Trade and Investment}

India is Nepal's largest trade partner and the largest source of foreign investments, besides providing transit for almost entire third country trade of Nepal. India accounts for over two-third of Nepal's merchandise trade, about one-third of trade in services, $36 \%$ of foreign direct investments, almost $100 \%$ of petroleum supplies (Indian Embassy to Nepal, 2017). Nepal has huge trade deficit with India and it is growing every year.

Indian firms are the biggest investors in Nepal, accounting for about $38.3 \%$ of Nepal's total approved foreign direct investments. There are about 150 operating Indian ventures in Nepal engaged in manufacturing services, banking, insurance, dry port, education and telecom, power sector and tourism industries.

\section{Education}

Indian government is providing around 3000 scholarships/seats annually to Nepali nationals for various courses at the $\mathrm{Ph} \mathrm{D}$, master, bachelor and plus-two levels in India and in Nepal. 


\section{Indian Community in Nepal}

Around 6, 00,000 Indian national have been living in Nepal and around 10,00,000 Nepalese nationals have been working in different parts of India (Nepal India relation, 2017). Nepal and India have got open border. There is a people to people relation among the Indian and Nepalese people whether it is in the east or west brooder area.

\section{Recent Development in Nepal-India Relation}

There were ups and downs in Nepal-India relation in the past. At present also, Nepal and India have very volatile and unstable relation -sometime friendly and sometime hostile, although Nepal always wants to have stable relation with India. There has been lack of confidence and mutual trust to one another in NepalIndia relation after declaration of new constitution in 2015 that followed unannounced trade embargo from Indian side. Nepalese nationals' sentiment towards India is not good thereafter and people think that India has its own interests in Nepal's internal issues. So, in order to build good relation between Nepal and India, Indian government should respect Nepal's sovereignty and independence and all business dealings must be based on equal status. Indian government is directly and indirectly supporting to Madhes-based parties. Indian government through imposing undeclared blockage has violated Nepal's trade and transit right. Such influences could not promote good relation among adjacent neighbors. In Nepal India border, we can find many examples of marriage among Indian and Nepali people. India has reoriented its foreign policy to boost bilateral ties with Nepal, especially after Narendra Modi came to power in 2014. Another reason for the Modi government to engage Kathmandu at the highest political level is China's increasing investment in infrastructure, energy and other sectors of Nepal. 
The Federal Democratic Republic of Nepal has traditionally maintained a non-aligned policy and enjoys friendly relations with neighboring countries. As a small, landlocked country wedged between two larger and far stronger powers, Nepal maintains good relations with both countries the People's Republic of China and India. Since the establishment of diplomatic relations between Nepal and China, the rivalry between India and China has been increasing on Nepalese soil. India wants to uphold its traditional leverage in Nepal; whereas China wants to puncture this relationship and seeks its own space in different layers of administration, security agencies, army and not the least among the people (Jha, 2010). Nepal remains poor and deprived in $21 \mathrm{st}$ century while India has acquired a central place in the world with a very high development rate (Kavitha, 2016).

The India-Nepal Treaty of Peace and Friendship of 1950 forms the bedrock of the special relations that exist between India and Nepal. At that time there was autocratic Rana regime and close society in Nepal. People had started getting organized against the Rana rulers and the Rana rulers too were just thinking how to prolong their rule. The treaty signed in such a context is not suitable for present democratic situations. Under the provisions of this Treaty, the Nepalese citizens have enjoyed unparalleled advantages in India, which avalled facilities and opportunities at par with the Indian citizens. The Treaty has allowed Nepal to overcome the disadvantages of being a land-locked country. Beginning with the 12-Point Understanding reached between the Seven Party Alliance (SPA) and the Maoists at Delhi in November 2005, the Government of India welcomed the roadmap laid down by the historic Comprehensive Peace Agreement of November 2006 towards political stabilization in Nepal through peaceful reconciliation and inclusive democratic processes. 
Nepal and India are so well bounded by various social, economic, geographical, cultural, and religion ties (Saran, 2017). Basically, Anti India sentiment is growing in Nepal especially after Indian blockade of 2015. Treaties concluded between the two countries in different times have always remained debatable. By realizing the fact, a joint mechanism with a group of foreign policy expert called Eminent Persons Group (EPG) has started reviewing all the treaties previously signed between Nepal and India (The Kathmandu Post, 6 July, 2016;1)

\section{Conclusion}

Nepal has age old and deep rooted relations between both China and India. Nepal-China and Nepal-India relations have evolved through different circumstances, stages and periods till date. Nepal-China and Nepal-India relations have multitude linkages- ranging from social, cultural, religious, geo-political, and economic to diplomatic affairs. One belt one road is the milestone point for both Nepal and China of 21st century. There is more mutual trust and less - or no disagreement-in NepalChina relations but there are less mutual trust and more disputes in Nepal-India relation. The greatest challenges in Nepal's foreign relations, at the present context, are: to build good mutual trust and win confidence Indian from in Nepal-India relations, to maintain balanced and equal distance in relations with China and India, to make China and India join hands together for broader, deeper and stronger economic ties for equal mutual benefits of all. After the declaration of new constitution and new election being held under it, China and India must be ready in re-structuring foreign affairs with Nepal in the changed perspective from newer dimension. Also, economic growth, development and prosperity must take central stage while redefining and revising the oneto-one and triangular relation between Nepal, China and India, 
keeping respect for each other's national sovereignty, integrity and independence intact. In conclusion, Nepal's foreign relation with China and India must be directed towards regional peace, integrity and prosperity.

\section{References}

Bhandari, Bibek (2017). China's Cultural debt to Nepalese artist in the $13^{\text {th }}$ century court of Kubal Khan. http://www.scmp. com/magazines/post-magazine/long-reads/article/2122813/ chinas-cultural-debt-nepalese-artist-13th-century

Bhattari, Rajan (2005). Geopolitical specialties of Nepal and international approach to conflict transformation, Nepal: Friends for Peace in Jan 2005. https://indiamadhesi.files. wordpress.com/2008/10/geopolitics-of-nepal.pdf

Bhattari, Rajan (2013). Foreign Policy in Nepal, Kathamandu: Maratin Chautari, http://nepalpolicynet.com/images/stories/ happenings/130526_Invitation_Policy\%20Discussion Copy.pdf

Chinese Buddhist Encyclopedia.

Dahal, G. (2015). Constitutional Assembly of Nepal Milestone for Peace, Development and Political Stability: KMC Journal of Interdisciplinary Studies, Vol.4.1, p.70-77.

Embassy of Nepal WashingtonDC,http://www.nepalembassyusa. org/guiding-principles/

Embassy of Nepal (2015). http://www.nepalembassy.org/ guiding-principles/

Government of Nepal Ministry of Foreign Affairs MOFA http:// mofa.gov.np/foreign-policy/diplomatic-relations/

Government of Nepal Ministry of Foreign Affairs MOFA http:// mofa.gov.np/foreign-policy/foreign-policy/ 
Indian Embassy to Nepal (2015). http://np.india-embassy.org. http://countrystudies.us/nepal/64.htm http://mof.gov.np/ieccd/newsbook/20140820115245.pdf http://mofa.gov.np/foreign-policy/diplomatic-relations/ http://mofa.gov.np/foreign-policy/foreign-policy/ http://mofa.gov.np/nepal-china-relations/ http://np.china-embassy.org/eng/ChinaNepal/t362330.htm http://www.mea.gov.in/Portal/ForeignRelation/8_Nepal_ November_2017.pdf http://www.mea.gov.in/Uploads/PublicationDocs/191_ panchsheel.pdf

https://archive.org/stream/nepalbhutancountsava/ nepalbhutancountsava_djvu.txt

https://www.indianembassy.org.np/pdf

https://www.mea.gov.in/Images/pdf

https://www.mea.gov.in/Portal/ForeignRelation/Nepal_ July_2014_.pdf

https://www.mea.gov.in/Portal/ForeignRelation/Nepal_ July_2014_.pdf

India-foreign-relation-2012.pdf

Jaishankar, Dhruva (2016). India's Five Foreign Policy Goals: Great Strides, Steep Challenges, https://www.brookings. edu/opinions/indias-five-foreign-policy-goals-great-stridessteep-challenges/

Jha, Hari Bansh (2010). Nepal's Border Relations with India and China http://src-h.slav.hokudai.ac.jp/publictn/eurasia border_review/Vol41/V4N104J.pdf 
Kavitha K K, (2016). The Changing Paradigm of India- Nepal

Relations: Problems and http://www.questjournals.org/ jrbm/papers/vol4-issue5/B451015.pdf

Saran, Shyam (2017). How India Sees the World. New Delhi: Juggernaut Books.

Savada, Andrea Matles (1991). Nepal and Bhutan: Country Studies,

Shivakoti, Gopal (2013). Dictionary of Politics Nepali-EnglishNepali, Kathamandu: Pairavi Prakashan.

Shrestha, Rajendra B. (2018, 1 Janaury). Foreign Policy Challenges and Opportunities, Kathamandu : The Rising Nepal.

Subedi, Suryaprasad (2016). Kathamandu, Kantipur Publication. The Kathamandu Post (2017, 4 March). Kathamandu, Kantipur Publication.

The Kathmandu Post (2016, 6 July). Kathamandu, Kantipur Publication.

Xinhuanet (2018). Chinese tourists flock to Nepal during Chinese New Year http://www.xinhuanet.com/english/201802/18/c 136983861.htm. 


\section{A Peer-Reviewed Article}

\section{Parties' Polarization and their Impact on Democracy}

Kapilmani Dahal

\section{Abstract}

Political parties are the major agents of a political process. In the democratic system of governance, political parties are thought to be the inevitable factors. Political parties are said to be as the lubricant oil of democracy, engine of democracy, fuel of democracy, life line of democracy and energy of democracy in the democratic system. Democracy is the political system which is regulated and performed by the political parties. For the well functioning of a democratic system, the political parties should follow perform the democratic values and norms properly. All the parties but mainly the ruling party or parties should be always committed towards the achievement of democratic values. Party may be polarized but they should not be polarized for and against the democratic norms and values. When political get parties polarized going for and against constitutional guidelines then it may be proved disastrous for democracy. Now in Nepal political parties have been polarized making their own alliance during the election time. Left alliance has declared that they will make the unified single communist party for political stability and economic prosperity. Democratic alliance mainly Nepali congress has claimed that left alliance is not for nation but for imposing totalitarianism and authoritarianism in the country. Polarization of political party will bring both the positive and negative impacts in the democratic polity. To make success the democratic system of governance, party may be polarized and unified but they must not to be polarized to make weaken the democracy. The major objectives of this article are to show the 
major values of democracy, to show the patterns of polarization of political parties and to analyze the impacts of polarization of political parties. To meet these objectives descriptive-analytical methodology of study has been applied. To draw the conclusion, both qualitative and quantitative information have been taken from secondary method.

Keywords: Alliance, democracy, political party, polarization, performance

\section{Introduction}

Political party and democracy are the two important variables in a political system. Political systems can be termed open or closed system on the basis of the existence of these variables in the practice. Democracy is a political system which totally depends on the political parties. On the another, hand democracy is the ends and political parties are the means in the political system. Renewal of democracy is done by the political parties and election is the best way of renewal of democracy. Democracy has various values which can be achieved by means of political parties. Democracy becomes possible in the practicability of political parties. The life of democracy depends on the reliability of political parties. So, for the success of democracy, the political parties which have been formed to worked in accordance with the spirit of the constitution, have to work co-operatively. Unity of Political party is inevitable for the successful working of democracy. Fragmentation of political parties affects directly in the performance of democracy. For the well- functioning of democracy, political parties must be committed towards the democratic norms and values both in principle and practice. One thing in the principle but the opposite in practice by political parties hampers the democracy. Where political parties are not responsible towards the constitution and its core values, 
democracy cannot sustain there for long time. Multi parties system of politics is necessary for sustaining democratic practices.

\section{Objective of the Study}

The objectives of this study are to show the democratic values mentioned in the constitution, to show the patterns of polarization of political parties and to analyze the impacts of polarization of political parties in the performance of democracy.

\section{Methodology}

Methods in political science are used differently according to the subject matter of study to link the statement of problem and objectives. This article covers the contemporary issues. So to describe the contemporary issues, descriptive-analytical methods of study have been used in this article. Information has been taken from secondary sources. Qualitative and quantitative data both have been used to analyze the variables. Values of democracy have been taken from the constitution of Nepal. Numerical data have been taken from election commission of Nepal and other Secondary information has been taken from library method.

\section{Political Parties and Democracy}

Political parties are thought inevitable in a democratic polity. During the Panchayat System in Nepal, political parties were thought negatively. At that time political party was thought to bring about cliques and unnecessary conflict in the society. But after multiparty party system, got changed political parties are supposed to be the major tools for a political process.

There are various definitions of political party. Burk signifies that a political party "is a body of men united for promoting the 
national interest on some particular principles in which they are all agreed" (Johari, 1998). Disraeli described political party as a group of men banded together to pursue certain principles (Jupp, 1966:2). According to Benjamin constant, a party is a group of men professing the same political doctrine (Duverger, 1964: xiv). Political party is first of all an organized attempt to get power, but it is equally just to say that parties are held together by the cohesive power of public plunder (Schattschneider, 1942: 35-37). Political parties are also said as a vote-catching machine or an agency to mobilize people's support for a candidate at the polls, or an instrument for the aggregation of interests that demand their vociferous articulation. According to Newmann, political parties are the articulate organization of the society. Epstein treats political party as any group of seeking votes under a recognized label (Epestein, 1967: 9). Political party is an organization specialized with regard to presenting candidates and issues under its own name in the elections. Likewise, Kaplan said that political party is a group formulating comprehensive issues and submitting candidates in the elections (Sartory: 62). Riggs has written that political party is any organization which nominates candidates for elections to an elected assembly (Riggs, 1970: 580).

On the ground of aforementioned definition we can say that political parties are synonymous to politics. Only political party can play the pivotal role in the politics. Politics cannot run without political party in the democratic system. On the basis of inevitability of the political party in democracy it can be said again that every politics is party politics and the politics without party is the Barron politics.

The term democracy has been defined by various scholars. All catch up the definition that democracy is a system of 
governance of the people, for the people and by the people, according to the Abrham Lincon. Generally democracy is a way of life and not only the political system. Democracy is concerned with democratic idea, democratic institution and democratic practice (Dreje and Sen, 2002:346). If the liberal democratic system stands on the foundation of democracy, it also recognizes certain assumptions. In this system government is supposed a mean not an end. Liberal democratic state desires a pluralistic society (Finer, 1970:65). According to Ball (1971) multiparty system, periodic elections, openness in the process of political recruitment, open competition, pressure groups and their influence in the government, civil liberties, independent judiciary and mass media to criticize the government are the characteristics of liberal democratic system (Ball, 2071: 46-47). These are the values of democracy.

Democracy has become the most popular political terminology. According to the Collins' dictionary, democracy is a system of government by the whole population or all the eligible members of a state, typically through elected representatives. It is a system of government in which people choose their rulers by voting for them in elections. It is also a system of running organizations, businesses, and groups in which each member is entitled to vote and take part in decisions. Political parties are the foundation of democracy but according to Kraemer (1994) all political parties are facing problems with implementing intra-party democracy in Nepal (Kramer, 1994). Democracy is the most widely admired political system, but perhaps the most difficult to maintain. Democracy begins with excellent objectives in human governance with unquestioned intentions to impart freedom from injustice and social exclusion. The civil society groups, political parties and media have a significant role to play in making certain sense of democratic values and Parties' Polarization... Kapilmani Dahal - 66 - 
behavior amongst all citizens (Ranjan, 2017).

Dev Raj Dahal writes that the elongated political transition in Nepal so far signifies that the mainstream parties-NepaliCongress, Communist party of Nepal Unified Marxist Leninist, United Communist Party of Nepal -Maoist and United Democratic Madhesi Front - lack a shared vision, skill and ability to steer rule base governance, institutionalize and consolidate democratic gains, seek institutional stability, strengthen popular sovereignty through local governance, beef up the intermediary institutions of society ,and meet the expectations of ordinary citizens for public good (Dahal, 2014:1-2). Certainly the challenges shown by him are also the same in the present context also. He has further mentioned that a democratic leader never loses sight of the balance between four core elements: acquisition of power, maintenance of democratic ideas, promotion of social wellbeing of the people and constructive change in the society which makes violent conflict redundant (Dahal, 2014:13). Hachhethu at all (2008) have written that Nepal is in a state of transition. The political actors in Nepal must use this transitory period to formulate a vision for Nepal's future and they must create a road map that will take Nepal to the destination thus envisioned. Nepal is still in transition and to end it leadership should show the ability to make decision and implement it with the vision.

Nepal's political leaders should focus on economic development and growth in parallel to their efforts to make their country is political transition process forward. Nepal's democratic institutions remain weak and allow a culture of political Impunity and patronage to continue to thrive. A key area of building strong institution is political party reform in Nepal (Report by Carter Centre, 2009-2014).

A system becomes stable when it is effective and stable and 
legitimate at the same time. A regime which is relatively low in effectiveness but has a high degree of legitimacy can survive longer than an ineffective and illegitimate regime (Adhikari and Timberlake, 2007:9). Political parties are indispensable for working of modern democratic governments. The importance of political parties lies in the fact that democracies can't function without the existence of political parties (Goel, 2015). Nepalese democratic exercise was in crisis. In the ongoing crisis of Nepalese politics, people's second movement, 2006 has just been completed demanding complete inclusive democracy (Baral, 2006). Nepal's democracy did not sustain for long time. Now, the country must go ahead with full democracy including implementation of democratic values.

\section{Constitutional Provisions about Political Party}

The constitution of Nepal has started with the preamble. The first line of preamble has mentioned that-"we the sovereign people of Nepal", it signifies that the sovereign power of people is exercised by the political party. Such as the exercise of provision relating to people's sovereign right and right to autonomy and self-rule will also be possible by the political party. In the preamble it has also mentioned that being committed to socialism based on democratic norms and values including the people's competitive multiparty democratic system of governance. It is also related to political party. Federal democratic republican system of governance of Nepal will be run with political party. So, our constitution has accepted the crucial role of political party in the political system.

According to the provision made in the constitution of Nepal in the article 2, the sovereignty and state authority of Nepal shall be vested in the Nepalese people. It shall be exercised in accordance with the provisions set forth in the constitution. It is 
clear that sovereign and state power of people shall be exercised only by the political party.

Provision about political party can be found in the section under the fundamental rights and duties. There is provision of freedom of opinion and expression, freedom to assemble peaceably and without arms, freedom to form political parties in the article 17(2) a), (b) and (c) respectively. These provisions are the pivotal provisions about political parties. But there are some restricted clause or e limitations for exercising those fundamental rights. Right to social justice is also attached with political party because first of all political party should be responsible for guaranteeing the right to participate in the state bodies on the basis of proportional inclusive principle. All forms of legislative and executive organs of government (Centre, Province and Local Level) shall be run by the political party.

The provision about political party has been made in the constitution on part-29 under the provisions relating to political party. According to the provision political party should be formed on the basis of law made accordance with article 17 (2) (c) of constitution. To form the political party the people to be committed to common political ideology, philosophy and program subject to law. Application must be given to the election commission with manifesto for its registration. The constitution has made provision for not prohibition on imposition of registration on political party if they are not inconsistent with the constitution. According to the constitutional provision registration is required for securing recognition for the purpose of contesting election as political party. Other matters pertaining to the political party shall be as provided for in the federal law.

Political party is thought negatively as destructive body like a clique or faction in the beginning time. Now political party is 
thought inevitable factor in the political process. There are various views about political party. Liberal view and Marxist view are two important views analyzing the political party. Political party is the group of people professing the same political doctrine. In the party system, group of people are banded together to pursue the same political doctrine. Political party is determined by different factors. Historical factor, socio-economic factor and ideological factors are three important factors which make the political party more influential among the people.

\section{Political Parties and Their Polarization}

Political parties are inevitable in the politics but their polarization brings both the positive and negative impact in the politics. Stable polarization generally in two polar may bring positive impact but instable polarization and changing the alliance time to time being centric to own interest and benefit brings negative impact in the politics although political party must change its plan, policy and program according to the pace of change and needs of the society. As per the needs and demands of society, almost closing party who are applying the matching principles may stand in one polar. They can make alliance and influence the politics. It may maintain the political stability where politics has made the permanent house of political instability. After the alliance of political party, the culture of bi-party system can be established. But in the case of following the power centric politics by political energies then, it can be proved further more disastrous in the politics. In the case of Nepal also it will be applicable.

\section{Multi-Party and Bi-Party System in Nepal}

Nepal is applying the multiparty system in the course of performance of democracy. Democratic constitutions of 
Nepal have accepted the multiparty system of governance. In the condition of multiparty system, party can be polarized differently. Generally political stability can't be maintained in this condition.

In the bi-party system there may be more than two parties but the politics and governance system may be influenced by two major parties and Party may be organized in two poles. Bi- party system does not mean that a particular country has only two parties and there is no third party in it. It means there are only two major parties and the rest of the parties are less important. For example there are more than two parties in England and United States of America. There are other parties but their influence in governance can't be felt. Where is multiparty system, there are more than two important parties in the political process. Nepal has also accepted the multiparty system of governance but gradually the culture of bi-party system of governance is also developing here after the parliamentary election held in 2074 Mansir 10 and 20.

\section{Merits of Bi-Party System}

Nepal is going to apply the bi-party system, so let's see the major merits and demerits of bi-party system of government.

The major merits of bi-party system are formation of stable government, Election is held for formation of government directly, easy to formation of government, strong and responsible opposition party, continuity in making and implementing the governmental policies and decisions, responsibility of government and its birthing party, decisive position of prime minister or pivotal position of prime minister and possibility of multi-dimensional development. 


\section{Demerits of bi-party system}

Demerits of bi-party system can be enumerated as; possibility of dictatorship of government, limited alternative to choose the political party, influence of ruling party on parliament, dictatorship of majority party, division of people in two poles, no representation of opinion of people in the parliament, possibility of division of political parties, possibility of spreading corruption, dominancy of immorality and Political opportunity for majority party or politicization of majority party.

\section{Election and Culture of Bi-party System}

Federal and provincial election has just been completed in Nepal. In this election political parties have gained the following result in federal house of representation.

\begin{tabular}{|l|l|c|c|l|}
\hline SN & \multicolumn{1}{|c|}{ Political Party } & $\begin{array}{r}\text { F.P.T.P } \\
\text { System }\end{array}$ & $\begin{array}{l}\text { P . R } \\
\text { System }\end{array}$ & Total \\
\hline 1 & $\begin{array}{l}\text { Communist Party of Nepal } \\
\text { U.M.L }\end{array}$ & 80 & 41 & 121 \\
\hline 2 & Nepali congress & 23 & 40 & 63 \\
\hline 3 & $\begin{array}{l}\text { Communist party of Nepal } \\
\text { (Maoist Centre) }\end{array}$ & 36 & 17 & 53 \\
\hline 4 & Rastria Janata Party Nepal & 11 & 6 & 17 \\
\hline 5 & Sanghiya Samajbadi Forum & 10 & 6 & 16 \\
\hline 6 & Rastria Prajatantra Party & 1 & & \\
\hline 7 & Naya Shakti Party Nepal & 1 & & \\
\hline 8 & Rastria Janamorcha Nepal & 1 & & \\
\hline 9 & Nepal Majdoor Kisan Party & 1 & & \\
\hline 10 & Independent & 1 & & \\
\hline & Total seats & 165 & 110 & 275 \\
\hline
\end{tabular}

Source: Election commission of Nepal: 2074 According to the provision made in the act relating to the Parties' Polarization... Kapilmani Dahal - 72 - 
political party 2074, political party must secure at least one seat in the federal parliament in house of representative in first past the post system or plural system and at least three percent in proportional list system based on list system. Political party, if they could not secure at list one seat in house of representative system and at least three percent in list system simultaneously, they can't be the national party. Because of not meeting the criteria Rastria Prajatantra Party, Rastria Janamorcha Party and Naya Shakti Party couldn't enlist themselves to be national party and their winner candidates became independent in the parliament. Rajendra lingdel, Durga Paudel,Baburam Bhattarai and Prem suwal became independent in this respect. Lama had already won the election being the independent candidate. Parties not being able to meet the criteria, lost their image of national party. Their vote, secured under list system became valueless while declaring parliamentarian under the list system. CPN UML secured first position both in the FPTP electoral system and PR system. Nepali congress became the third largest party in the FPTP system and second position in the PR system and became over all second largest party in the house of parliament. CPN Maoist center became the second largest party in the FPTP system and third largest party in the PR system and in over all this party became third largest party in the house of representative. In the list system UML obtained 3173494 votes, Congress 3128389, Maoist center 1303721, Forum 470201, R Janata party 472254, Bibekshil sajha 212366, RPP 196782, RPP (P) 88377, R Janamorcha 62133, Naya Shakti 81000 and other obtained 355190 votes. According to the constitutional and legal provisions, only five parties who obtained more than three percent in the PR system and at least one seat in first past the post system became the national party. To form the majority government single party must have secured 138 seats but no 
parties have secured it. Left alliance could not obtain two third majorities in the house of representative. It indicates that people have given mandate to political parties to follow the consensual politics in the national issues mainly to amend the constitution. Madhesh based political parties, UML and Maoist Centre with their unanimous opinion can amend the constitution.

\section{Democratic Values}

Nepal is applying democratic system of governance. The constitution of Nepal has accepted some values of democracy as its guidelines of governance. The constitution is the guide line or compass that directs the political process. Democratic values mentioned in the constitution are commonly accepted values. So they must be obeyed by the political parties. When political parties ignore them, then they may bring negative impacts in the political process. So, political parties must be aware for the performance of democratic values. Majority party or ruling party must be most responsible for these values. When the political party became polarized on democratic values then democracy may be far from the people and not for the people. Some democratic values, accepted by the constitution of Nepal are the competitive multi-party system of governance, Civil liberties, Fundamental rights, Human rights, Adult franchise, Periodic elections, Complete freedom of press, Independent impartial and competent judiciary, Rule of law, Constitutionalism, Guarantee of basic rights of the people, Peace, prosperity and progressive socio-economic transformation of society, Sovereignty, integrity and independence of country, Federal democratic republican system, Sense of nation and nation building, Democratic and progressive change, Ending of all forms of discrimination and oppression, Protecting and promoting social and cultural solidarity, Tolerance and harmony of the people, 
Unity in diversity, Proportional inclusive and participatory principle, Economic equality, prosperity and social justice, Socialism based on democratic norms and values, Sustainable peace, good governance, development and prosperity through the federal, democratic, republican system of governance, People's sovereignty, right to autonomy and self rule and so on other values mention in the constitution in the preamble and overall in the constitution (Constitution of Nepal, 2015). These values should be performed by majority party who forms the government.

\section{Polarization and Its Impacts}

Nepalese political parties have been polarized affected by the constitutional and legal provisions relating to political party and electoral system. House of Representatives of Federal parliament is the government making institution. There are two types of electoral system for the lower house of parliament. By the provision, there is very difficult to form a majority government by the single political party. So, alliance of political party is inevitable to win the election and to form the government post the election. For these purpose, Nepalese political parties polarized on two poles mainly, democratic pole headed by Nepali Congress and left pole headed by CPN UML and CPN Maoist Alliance. However, there are Madhes based parties where Sanghiya Samajbadi Forum and Rastriy Janta Party Nepal have become the national party. They have raising the voice of Madhesi people. What types of role they shall play in the federal parliament and in provincial Assembly, it will influence the major polarization of political parties in Nepal. Government both in centre and province will be affected by the polarization of political party. Election has just concluded in Nepal in Mansir 10 and 21, 2074 BS. Nepali Congress party 
has lost its first position and became second largest party. It is certain has become certain that Nepali Congress Party will be opposition party if government is formed jointly by left alliance or left alliance made the single communist party. If not so, the politics of Nepal will be rounded to other direction also, in this situation the left and democratic alliance will be affected.

The polarization will create both the positive and negative impacts in the Nepalese politics. The positive impacts will be seen as corresponding to its merits mentioned earlier. The negative impacts will also be seen as corresponding to its demerits mentioned earlier. However, in Nepalese context in addition to earlier negative impacts, the other negative impacts will also be created here. According to the constitutional provision, regarding formation of government and its removal in Nepal will create the possibility of division in the political party to lead the government. The provision of necessary to obtain the vote of confidence in case of splitting of political party advanced to two year of formation of political party, will hamper the political process. It shows the possibility of splitting in political party and political instability in Nepal. In case Communist alliance could not make the single party, then government changing pattern will be repeated in Nepal. There is possibility of politicization of socialism based on democratic values. The term socialism will be made debated. If left government shows trends of communism and authoritarianism, then there will be also the chance of danger of military intervention because military always stands on the opposition of communist government. Military may think that communist government will cut off their facilities. So to control it, they should control the government. When they control the government once then, they want to impose their rule for ever.

So majority party must be conscious about this fact and 
they should not overrule the constitution, they should always follow the constitutional provisions. Misuse of power, over use of power and over rule of government will affect the political process. Idolization of government, end of representative inclusive democracy, danger in democracy in the name of democracy, misuse of resources, lack of constitutionalism and good governance, fear of impeachment, to be work in the favor of government due to the weapon of impeachment, oppression to opposition party by government might be seen as negative impacts. So the majority party will be always alert to safeguard democratic system based on constitutional values. Opposition party also must stand in favor of democratic constitutional values.

\section{Conclusion}

Nepal has become continuously the political laboratory of instability. The government is changing time to time which is not liked by people as a whole. People wanted to see the stable government at least for five years. Election of centre and province has been completed and the process of formation of new government is going ahead. It will be completed after few days and new government will start to run the country. On the other hand, according to the provision of threshold and proportional system, political parties had to be polarized pre or post the election. It was their compulsion and for it they made democratic and left alliance as different poles. Small parties were opposing the threshold. They wanted to remove it. They had argued that if threshold is necessary, it should not have the provision of one percent. People were in favor of at least three percent's threshold. Major political parties came in favor of threshold at last and it became possible. To remove small parties' dominancy in the government and to make stable government, 
threshold was thought necessary. Parties stood on deferent poles to win the election and form a stable comfortable government. Two major communist parties made alliance and represented one pole and Nepali congress automatically represented another pole.

Standing on deferent pole is not so important; important is that how they will perform the democratic values either being governing parties or being oppositional parties. To make the strong democracy political parties must stand in favor of constitutional democratic values. Madhesh based parties have maintained their own political stream. Which pole they will support it is not clear. However their support will be important for the amendment of the constitution and form a waiting government. If UML and Maoist centre broke their alliance or could not make and sustain the single political parties then there will be possibility of forming the government out of UML. It seems that the life of communist led pole will be deepening on the support of two major communist parties each other. Political parties have been polarized mainly in two poles. Democratic and left alliance was its product. Political party participated in the election making their own alliance. Alliance must be made but it may be made post the election also. Political parties made it before the election. It made easy to contest the election but made complex to understand the actual position of political party.

Election changed the position of political party. CPN UML became the largest party which was second largest party in the earlier election. Maoist centre became the third largest party which was in third position in the earlier election and Nepali congress became the second largest party which was the first largest party in the earlier election held in 2070BS. Left alliance has declared that will not only make alliance in the election but 
they will make the single party post the election. People put faith on it and they won the election. Political parties have secured their own seats.

After the declaration of final electoral result by election commission the process of formation of government will be started and government will be formed. Scenario has shown that the government will be formed by left alliance. After the formation of government, their works will or will not affect the performance of democratic values, mentioned in the constitution that will be seen in the future and it has become the great concern of people. However, the polarization of political party had become inevitable in the political process. After the formation of government, there may be seen impacts of polarization of political party in the performance of democracy. We expect it may bring the positive impacts in actual practice. The creation of unnecessary fear of impeachment, punishment, unnecessary amendment of the constitution, removal of democratic values, idolization of government, polarization of administration, lack of rule of law, bad governance and works against constitutionalism will not be done by the ruling party. Political parties must obey the democratic values to sustain and strengthen the democracy.

\section{References}

Adhikary, P. and Timberlake, J.D. (2007). Pursuing Democracy: Explaining Political Transition in Nepal, also visit in http:// digital repository.unm.edu.research $\mathrm{H} 5$

Agrawal, R.C. (2012). Political Theory. New Delhi: S Chand and Company.

Ball, A.R. (2071). Modern Politics and Government, London: Macmillan.

Baral, L.R. (2006). Nepal Quest for Participatory Democracy. New Delhi: Adroit Publisher 
Baral, L.R. (2006). Oppositional Politics in Nepal, Lalitpur: Himal Books.

Carter Centre's final Report (2009-2014). Political Transition Monitoring in Nepal.

Chaturvedi, R.R. (2017). Democracy in Nepal: Issues and Challenges. India: SSPC.

Dahal, D.R. (2014). The Role of Political Parties in Deepening Democracy, Kathmandu: FES

Dreze, Jean and Sen, Amartya (2002). Development and Participation, New Delhi: Oxford University Press.

Duverger, Maurice (1964). Political Parties: Their Organization and Activity in the Modern State, translated from French to English Language by Barbara and Robert North, London: Methuen.

Election Commission of Nepal (2074)

Epstein, L.B. (1967). Political Party in Western Democracy,

New York: Praeger.

Finer, S.E. (1970). Comparative Government, London: Allen Lane.

Goel, A. (2015). Political Parties: 5 Major functions of Political Parties in Democracy.

Government of Nepal (2074). NLBMC, Kathmandu: Act relating to federal House of Representative.

Government of Nepal (2074). NLBMC, Kathmandu: Act Relating to Political Party.

Government of Nepal (2074). NLBMC, Kathmandu: Act Relating to the Provincial Assembly.

Government of Nepal(2072). NLBMC, Kathmandu: Constitution of Nepal.

Hachhethu, K. Sanjaya Kumar and Subedi, J. (2008). Nepal in Transition. Kathmandu: International IDEA.

Johari, J.C. (1998). Comparative Politics, New Delhi: Sterling Parties' Polarization... Kapilmani Dahal - 80 - 
Publishers Pvt Ltd.

Jupp, J. (1968). Political Parties, London: Routledge and kegan Paul.

Kraemer, K.H. (1994). Democratization and Political Parties in Nepal, Heidelberg University.

Riggs, F.W. (1967). The Theory of Political Development.

Free Press: Macmillan .(Quoted in Johari J. C. (1998) Comparative Politics.

Schattschneider, E.E. (1942). Party Government, New York:

Holt and winston.

Sartori (1976). Party and Party System: A Framework For Analysis. London: Cambridge University Press. 